\title{
Enhanced Catalytic Degradation of Acid Orange 7 Dye by Peroxymonosulfate on $\mathrm{Co}_{3} \mathrm{O}_{4}$ Promoted by $\mathrm{Bi}_{2} \mathrm{O}_{3}$
}

\author{
Vanina Ivanova-Kolcheva, ${ }^{1}$ Labrini Sygellou ${ }^{2}$ and Maria Stoyanova ${ }^{2, *}$ \\ ${ }^{1}$ Department of Physical Chemistry, University of Plovdiv 24, Tsar Asen Str., 4000 Plovdiv, Bulgaria \\ ${ }^{2}$ Foundation for Research and Technology, Institute of Chemical Engineering Sciences (FORTH/ICE-HT), \\ Patras, GR-26504, Greece \\ *Corresponding author: E-mail: marianas@uni-plovdiv.bg \\ tel: +35932261248 fax: +35932261403
}

Received: 10-16-2019

\begin{abstract}
In this study, $\mathrm{Bi}_{2} \mathrm{O}_{3}-\mathrm{Co}_{3} \mathrm{O}_{4}$ composite oxides were prepared and their catalytic efficiency to activate peroxymonosulfate (PMS) towards the degradation of Acid Orange 7 dye (AO7) was evaluated. The characterization of the synthesized catalysts was carried out by XRD, TEM, XPS, FT-IR, and ICP-OES analyses. The increased basicity of the $\mathrm{Bi}_{2} \mathrm{O}_{3}-\mathrm{Co}_{3} \mathrm{O}_{4}$ hybrids contributed to the much better catalytic activity in PMS activation resulting in a considerably higher rate of $\mathrm{AO} 7$ degradation compared to that obtained with bare $\mathrm{Co}_{3} \mathrm{O}_{4}$. The sample with $50 \mathrm{wt} . \% \mathrm{Bi}_{2} \mathrm{O}_{3}$ showed the best performance under a broad $\mathrm{pH}$ range with very low Co leaching of $72 \mu \mathrm{g} / \mathrm{L}$ even under acidic conditions. Degradation of $50 \mathrm{mg} / \mathrm{L} \mathrm{AO} 7$ reached almost $100 \%$ within a short duration of $12 \mathrm{~min}$ by using very low catalysts concentration of $0.1 \mathrm{~g} / \mathrm{L}$ and [PMS]/ [AO7] $=6$. The influence of the $\mathrm{Bi}_{2} \mathrm{O}_{3}$ content, catalyst dosage, molar ratio of [PMS]/[AO7], initial $\mathrm{pH}$, and temperature on AO7 degradation were studied. Surface-bound sulfate radicals generated in the $\mathrm{Bi}_{2} \mathrm{O}_{3}-\mathrm{Co}_{3} \mathrm{O}_{4} / \mathrm{PMS}$ oxidation system were proved as the predominant radical species through radical quenching experiments.
\end{abstract}

Keywords: Acid orange 7 degradation; $\mathrm{Bi}_{2} \mathrm{O}_{3}-\mathrm{Co}_{3} \mathrm{O}_{4}$ catalyst; peroxymonosulfate; sulfate radicals

\section{Introduction}

Azo dyes represent one of the largest groups of organic pollutants in wastewaters, generally released from textile, leather, paper, printing, plastic, food, pharmaceutical and cosmetic industries. ${ }^{1,2}$ Dyes are not only highly visible, but also toxic, mutagenic, carcinogenic and low biodegradable. ${ }^{3-5}$ Therefore, these contaminants must be removed from wastewater prior to discharge into natural water bodies to prevent their detrimental effect to the natural ecosystem and human health. Due to the complex aromatic molecular structures of azo dyes, most of them are persistent and recalcitrant in the environment and therefore cannot easily be degraded by the conventional wastewater treatment processes. ${ }^{6-8}$ In the recent decade, the application of peroxymonosulfate (PMS) based catalytic oxidation processes for the degradation of several refractory organic contaminants in water including dyes has attracted increasing interest. ${ }^{9-13}$ PMS is capable of generating highly reactive radicals, such as sulfate radicals $\left(\mathrm{SO}_{4}{ }^{--}, \mathrm{E}^{\mathrm{o}}\right.$ $=2.5-3.1 \mathrm{~V})$ and hydroxyl radicals $\left(\cdot \mathrm{OH}, \mathrm{E}^{\mathrm{o}}=1.9-2.7 \mathrm{~V}\right)$, by activation through transition metals and their oxides, ${ }^{9-16}$ ultrasound, ${ }^{17,18}$ anions, ${ }^{19,20}$ and base. ${ }^{21,22} \mathrm{Com}$ pared to the $\bullet \mathrm{OH}, \mathrm{SO}_{4}{ }^{--}$has a longer lifetime $(30-40 \mathrm{~ms}$ vs $20 \mathrm{~ns}$ ) thus allowing it to react effectively with the target organic pollutant. ${ }^{23}$ Among the PMS activation methods, the most feasible route for production of $\mathrm{SO}_{4}{ }^{--}$radicals is catalytic activation by transition metal ions, with cobalt ions $\left(\mathrm{Co}^{2+}\right)$ being the best activator. ${ }^{14}$ Anipsitakis and $\mathrm{Di}-$ onysiou showed that $\mathrm{Co}^{2+} / \mathrm{PMS}$ could be an alternative method for degradation of organic compounds with excellent performance in neutral $\mathrm{pH}$, which is an applicable benefit of this system compared to the Fenton reagent. ${ }^{9}$ However, the difficult recovery of the homogeneous catalyst and especially the problem related to the potential environmental and health impact of cobalt in aquatic environment limit the practical-scale application of the homogeneous $\mathrm{Co}^{2+} / \mathrm{PMS}$ system. Therefore, the development of 
heterogeneous cobalt-based catalysts to activate PMS with low cobalt leaching is highly desirable. Among cobalt oxides, $\mathrm{Co}_{3} \mathrm{O}_{4}$ has been thoroughly investigated to activate PMS for degradation of various organic pollutants in water such as 2,4-dichlorophenol, ${ }^{24}$ phenol, ${ }^{25,26}$ antibiotics, ${ }^{16,27}$ and dyes. ${ }^{28,29}$ In order to enhance the catalytic performance and reduce cobalt leaching of $\mathrm{Co}_{3} \mathrm{O}_{4}$, several supports such as common oxide materials $\left(\mathrm{Al}_{2} \mathrm{O}_{3}, \mathrm{TiO}_{2}, \mathrm{MgO}\right.$, SBA-15), activated carbon, carbon nanofibers, zeolite, etc. have been used for hosting $\mathrm{Co}_{3} \mathrm{O}_{4}$ particles and tested for oxidative degradation of contaminants in the presence of PMS. ${ }^{10,30-35}$ Zhang et al. reported for a much better performance of $\mathrm{Co} / \mathrm{MgO}$ catalyst than bulk $\mathrm{Co}_{3} \mathrm{O}_{4}$ for degradation of methylene blue dye via heterogeneous PMS activation. ${ }^{30}$ The abundance of surface hydroxyl groups on the $\mathrm{MgO}$ support facilitate the formation of surface $\mathrm{Co}-\mathrm{OH}$ complexes, which is considered as the rate-limiting step for PMS activation. ${ }^{31} \mathrm{Co}_{3} \mathrm{O}_{4}$ supported on graphene oxide was prepared and used in the degradation of azo dye $\mathrm{AO} 7$ by advanced oxidation technology based on sulfate radicals. ${ }^{36}$ The $\mathrm{Co}_{3} \mathrm{O}_{4} / \mathrm{GO}$ nanocomposite exhibits a markedly better efficiency for PMS activation than both the homogeneous $\mathrm{Co}^{2+}$ and the heterogeneous unsupported $\mathrm{Co}_{3} \mathrm{O}_{4}$ catalyst due to the $\mathrm{Co}-\mathrm{OH}$ complexes formed on the surface of the GO sheet through the direct interaction of Co species with nearby hydroxyl groups. As the presence of surface basic sites can promote the formation of the surface $\mathrm{Co}-\mathrm{OH}$ complex, doping of $\mathrm{Co}_{3} \mathrm{O}_{4}$ with basic metal oxides would have a promotional effect on its PMS activation ability. Due to the high density of surface hydroxyl groups of the Bi-based materials, their synergistic coupling with $\mathrm{Co}_{3} \mathrm{O}_{4}$ can enhance its catalytic performance for PMS activation. ${ }^{37}$ The bimetallic Co-Bi oxide catalyst synthesized using a microwave-assisted method showed a much higher bisphenol A degradation and TOC removal efficiency via PMS activation than those of $\mathrm{Co}_{3} \mathrm{O}_{4} / \mathrm{PMS}$ and $\mathrm{Bi}_{2} \mathrm{O}_{3} /$ PMS systems. ${ }^{38}$

Herein, a performance evaluation of $\mathrm{Bi}_{2} \mathrm{O}_{3}-\mathrm{Co}_{3} \mathrm{O}_{4}$ catalysts as PMS activator for oxidative degradation of azo dye Acid Orange 7 is investigated. The kinetics of the oxidation process and the effects of various operational parameters, namely $\mathrm{Bi}_{2} \mathrm{O}_{3}$ content, catalyst dosage, molar ratio of [PMS]/[AO7], initial $\mathrm{pH}$, and reaction temperature on the catalytic efficiencies in $\mathrm{Bi}_{2} \mathrm{O}_{3}-\mathrm{Co}_{3} \mathrm{O}_{4} / \mathrm{PMS}$ system were studied in detail. Specific quenching studies were also carried out to identify the primary radical species formed from the catalyst-mediated decomposition of PMS.

\section{Experimental}

\section{1. Chemicals}

Cobalt nitrate $\left(\mathrm{Co}\left(\mathrm{NO}_{3}\right)_{2} \times 6 \mathrm{H}_{2} \mathrm{O}\right)$, bismuth nitrate $\left(\mathrm{Bi}\left(\mathrm{NO}_{3}\right)_{3} \times 5 \mathrm{H}_{2} \mathrm{O}\right)$, magnesium nitrate $\left(\mathrm{Mg}\left(\mathrm{NO}_{3}\right)_{2} \times\right.$ $\left.6 \mathrm{H}_{2} \mathrm{O}\right)$, Acid Orange 7 (AO7) and methylene blue (MB) were provided by Sigma-Aldrich (St. Louis, MO, USA).
Oxone $\left(2 \mathrm{KHSO}_{5} \cdot \mathrm{KHSO}_{4} \cdot \mathrm{K}_{2} \mathrm{SO}_{4}, 4.7 \%\right.$ active oxygen) was obtained from Sigma-Aldrich (St. Louis, MO, USA) and used as an oxidant. Other reagents were of analytical grade and were purchased as reagent grade. All chemicals were used as received without any further purification. Double distilled water was used to prepare solutions.

\section{2. Preparation of $\mathrm{Bi}_{2} \mathrm{O}_{3}-\mathrm{Co}_{3} \mathrm{O}_{4}$ Composite Catalysts}

The $\mathrm{x}-\mathrm{Bi}_{2} \mathrm{O}_{3}-\mathrm{Co}_{3} \mathrm{O}_{4}$ (x presenting the weight ratio of $\mathrm{Bi}_{2} \mathrm{O}_{3}$ to $\mathrm{Bi}_{2} \mathrm{O}_{3}-\mathrm{Co}_{3} \mathrm{O}_{4}$ composite, $\mathrm{x}=20 \%, 50 \%$, and $80 \%$ ) were prepared by co-precipitation method and subsequent annealing of the co-precipitated precursors. For the co-precipitation process, $0.8 \mathrm{~mol} / \mathrm{L} \mathrm{NaOH}$ was added dropwise at $333 \mathrm{~K}$ into a solution of metal nitrates containing $\mathrm{Co}^{2+}$ and $\mathrm{Bi}^{3+}$, taken in the specified stoichiometric ratio, under vigorous stirring until the solution $\mathrm{pH}$ reached 10 . The initially formed precipitate was kept under continuous stirring for 30 minutes at $333 \mathrm{~K}$. After filtration, the black product was washed with deionized water and ethanol several times to neutral $\mathrm{pH}$, dried at $378 \mathrm{~K}$ overnight, and finally calcined at $773 \mathrm{~K}$ for $3 \mathrm{~h}$ in static air. For comparison, pristine $\mathrm{Co}_{3} \mathrm{O}_{4}$ and $\mathrm{Bi}_{2} \mathrm{O}_{3}$ were also prepared by the same synthetic procedure.

\subsection{Characterization}

The Co and Bi contents in the composites as well as the concentration of leached Co ions after the reaction were determined by ICP-OES analysis on an iCAP 6300 instrument (ThermoFisher, MA, USA). The crystal structures of the synthesized catalysts were analyzed by X-ray diffraction. The powder XRD patterns were collected on a Bruker D8 Advance diffractometer (Bruker AXS, Billerica, MA, USA) equipped with $\mathrm{Cu} \mathrm{Ka}$ radiation and LynxEye detector. Phase identification was performed with the Diffracplus EVA using ICDD-PDF2 Database. The morphology of the catalysts was characterized by a JEM 2100 high-resolution transmission electron microscope (JEOL, Tokyo, Japan) using an accelerating voltage of $200 \mathrm{kV}$. Two basic regimes of microscope mode were used - bright-field transmission microscopy (TEM) and selected area electron diffraction (SAED). The surface elemental composition and chemical oxidation state were investigated by an X-ray photoelectron spectroscopy (XPS) on a UHV chamber $\left(\mathrm{P}<10^{-9} \mathrm{mbar}\right)$ equipped with a dual $\mathrm{Mg} / \mathrm{Al} \mathrm{X}$-Ray gun and a SPECS LHS10 hemispherical electron analyzer, using an $\mathrm{MgKa}(\mathrm{h} v=$ $1253.6 \mathrm{eV}$ ) X-ray source operated at $10 \mathrm{~mA}$ and $12 \mathrm{kV}$. The XPS spectra were analyzed with ECLIPSE using a Shirley background. The binding energies (BEs) obtained from the XPS analysis were calibrated with a reference $\mathrm{BE}$ of $\mathrm{C} 1 \mathrm{~s}$ $(284.8 \mathrm{eV})$. Fourier transform infrared (FT-IR) spectra were collected with a Vertex 70 spectrophotometer (Bruker Optics) using $\mathrm{KBr}$ pellets. The BET specific surface area of the samples was determined from the nitrogen adsorp- 
tion-desorption using a Tristar 3000 porosimeter (Micromeritics, Aachen, Germany) at the liquid nitrogen temperature. The $\mathrm{pH}$ of the point of zero charge $\left(\mathrm{pH}_{\mathrm{PZC}}\right)$ of the catalysts was determined by $\mathrm{pH}$ drift method. ${ }^{39}$

\section{4. Catalytic Degradation Procedure}

Batch experiments were carried out in a $400 \mathrm{~mL}$ glass reactor with constant stirring at around $400 \mathrm{rpm}$ at $293 \mathrm{~K}$. Typically, a certain dose of solid PMS (in the form of Oxone, $2 \mathrm{KHSO}_{5} \cdot \mathrm{KHSO}_{4} \cdot \mathrm{K}_{2} \mathrm{SO}_{4}$ ) was added into a $200 \mathrm{~mL}$ $50 \mathrm{mg} / \mathrm{L} \mathrm{AO} 7$ aqueous solution to attain the predefined PMS/AO7 molar ratio and stirred until dissolved. Degradation reaction was initiated by addition of a specified amount of catalyst. At the given time intervals, $4.0 \mathrm{~mL}$ of suspension was taken and quenched by $1 \mathrm{~mL}$ methanol to stop the reaction, and then centrifuged at $4000 \mathrm{rpm}$ for 1 min to remove the catalyst.

The concentration of AO7 was analyzed by UV-vis spectroscopy (Cintra 101, GBC Scientific Equipment Ltd., Australia) at a maximum wavelength of $486 \mathrm{~nm}$. All tests were conducted in triplicate to ensure the reproducibility of experimental results. For the quenching experiments, prior to the addition of oxidant and catalyst, a specified amount of radical scavengers was added into the AO7 solution to obtain a required scavenger/PMS molar ratio.

\section{Results and Discussion}

\section{1. Characterization of $\mathrm{Bi}_{2} \mathrm{O}_{3}-\mathrm{Co}_{3} \mathrm{O}_{4}$} Catalysts

The $\mathrm{Bi}_{2} \mathrm{O}_{3}$ content in the synthesized composite materials calculated on the basis of ICP-OES results was close to preparation settings $(25.7,52.9$, and $78.4 \mathrm{wt} . \%$ for the $20 \%$, 50\%, and $80 \% \mathrm{Bi}_{2} \mathrm{O}_{3}-\mathrm{Co}_{3} \mathrm{O}_{4}$ samples, respectively).

The crystal structure of $\mathrm{Bi}_{2} \mathrm{O}_{3}-\mathrm{Co}_{3} \mathrm{O}_{4}$ catalysts was analyzed by XRD and compared to that of pure $\mathrm{Bi}_{2} \mathrm{O}_{3}$ and

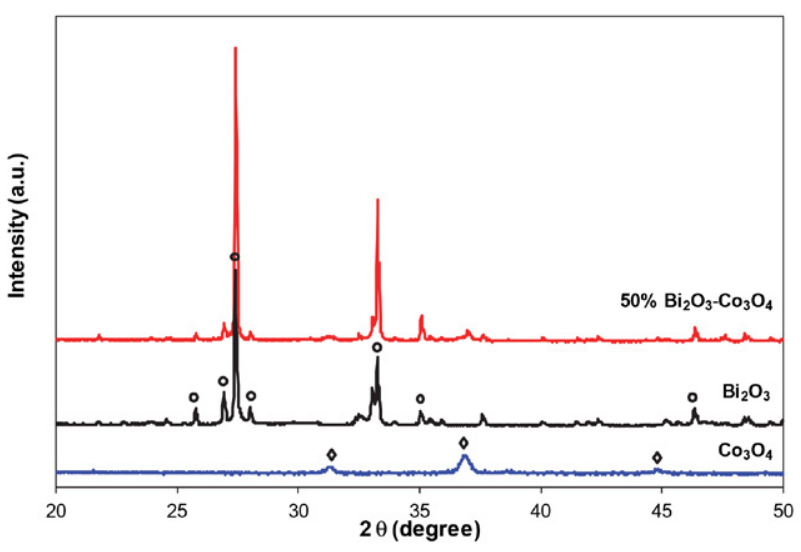

Fig. 1. XRD patterns of $50 \% \mathrm{Bi}_{2} \mathrm{O}_{3}-\mathrm{Co}_{3} \mathrm{O}_{4}, \mathrm{Co}_{3} \mathrm{O}_{4}$, and $\mathrm{Bi}_{2} \mathrm{O}_{3}$
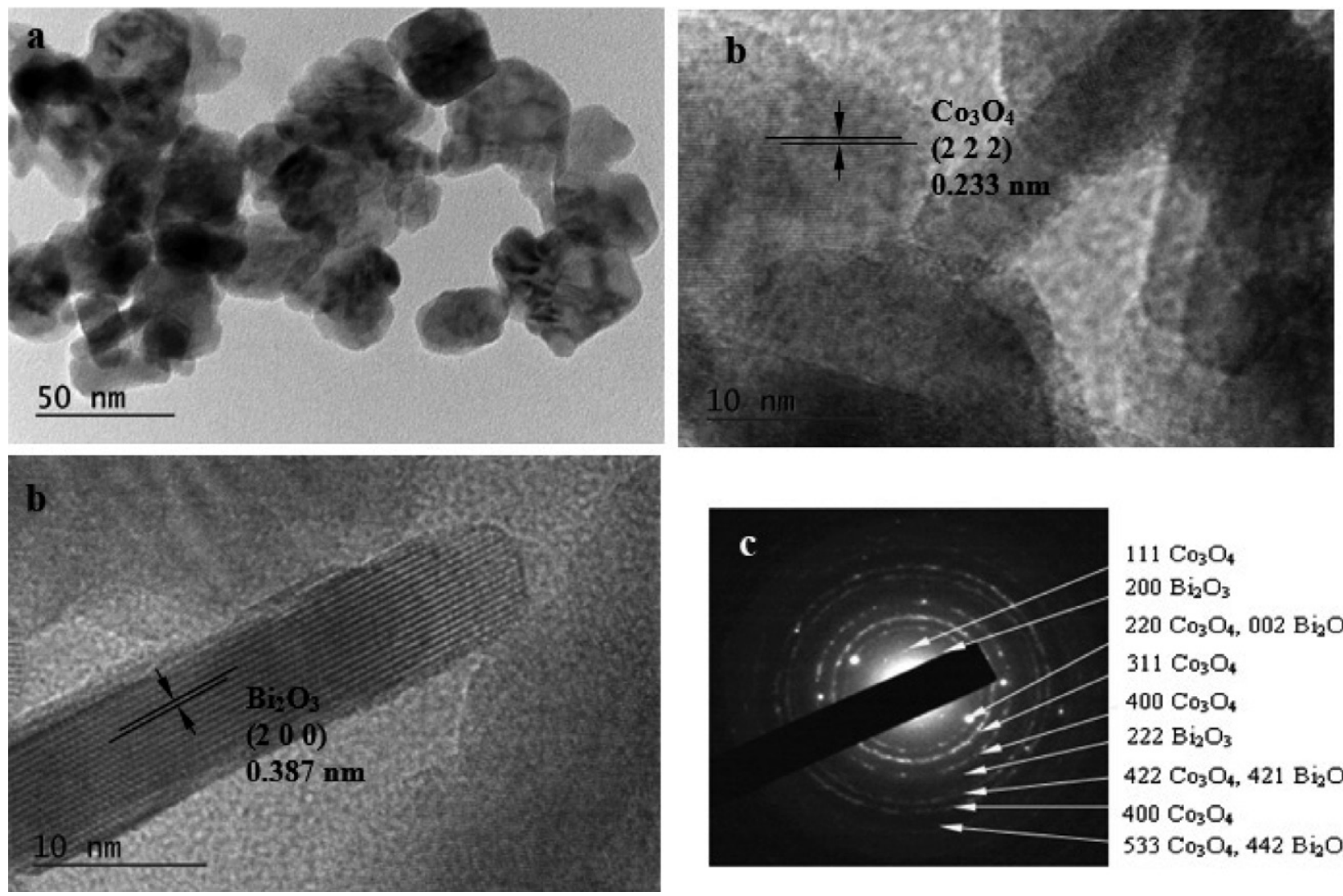
$111 \mathrm{Co}_{3} \mathrm{O}_{4}$ $200 \mathrm{Bi}_{2} \mathrm{O}_{3}$ $220 \mathrm{Co}_{3} \mathrm{O}_{4}, 002 \mathrm{Bi}_{2} \mathrm{O}_{3}$ $311 \mathrm{C}_{3} \mathrm{O}_{4}$ $400 \mathrm{Co}_{3} \mathrm{O}_{4}$ $222 \mathrm{Bi}_{2} \mathrm{O}_{3}$ $422 \mathrm{Co}_{3} \mathrm{O}_{4}, 421 \mathrm{Bi}_{2} \mathrm{O}_{3}$ $400 \mathrm{C}_{3} \mathrm{O}_{4}$ $533 \mathrm{Co}_{3} \mathrm{O}_{4}, 442 \mathrm{Bi}_{2} \mathrm{O}_{3}$

Fig. 2. (a) Bright-field TEM image, (b) HRTEM images and (c) SAED pattern of $50 \% \mathrm{Bi}_{2} \mathrm{O}_{3}-\mathrm{Co}_{3} \mathrm{O}_{4}$. 
$\mathrm{Co}_{3} \mathrm{O}_{4}$ (Fig. 1). The crystallographic phases of the prepared pristine oxides were confirmed as monoclinic $\alpha-\mathrm{Bi}_{2} \mathrm{O}_{3}$, (JCPDS 41-1449) and cubic spinel-type $\mathrm{Co}_{3} \mathrm{O}_{4}$ (JCPDS 421467), respectively. For the composite catalysts, the characteristic peaks of $\mathrm{Bi}_{2} \mathrm{O}_{3}$ were observed at about $2 \Theta$ values $26.93^{\circ}\left(\begin{array}{lll}1 & 1 & 1\end{array}\right), 27.40^{\circ}\left(\begin{array}{lll}1 & 2 & 0\end{array}\right)$ and $33.26^{\circ}\left(\begin{array}{lll}2 & 0 & 0\end{array}\right)$. The diffraction peaks at $31.2^{\circ}, 36.9^{\circ}$ and $44.7^{\circ}$ can be indexed to (220), (311) and (400) planes of $\mathrm{Co}_{3} \mathrm{O}_{4}$ crystal (JCPDS 42-1467). As seen in Fig. 1, reflections associated with cobalt species in $\mathrm{Bi}_{2} \mathrm{O}_{3}-\mathrm{Co}_{3} \mathrm{O}_{4}$ were too weak, suggesting good dispersion of the $\mathrm{Co}_{3} \mathrm{O}_{4}$ particles in the resulting product. Moreover, no positive shift of the diffraction peaks of $\mathrm{Bi}_{2} \mathrm{O}_{3}$ was registered in the composite catalyst, which suggests that $\mathrm{Co}$ species are not incorporated into $\mathrm{Bi}_{2} \mathrm{O}_{3}$ lattice and $\mathrm{Co}_{3} \mathrm{O}_{4}$ and $\mathrm{Bi}_{2} \mathrm{O}_{3}$ coexist in the composite.

The coexistence of $\mathrm{Co}_{3} \mathrm{O}_{4}$ and $\mathrm{Bi}_{2} \mathrm{O}_{3}$ phases in the composite catalysts was confirmed through TEM and HRTEM analysis. As observed in Fig. 2a, the 50 wt. $\% \mathrm{Bi}_{2} \mathrm{O}_{3^{-}}$ $\mathrm{Co}_{3} \mathrm{O}_{4}$ sample was composed of predominantly flat particles with a near-rectangular shape and size in the range of 30-50 $\mathrm{nm}$. The HRTEM image of the sample (Fig. 2b) showed well-defined lattice fringes, which indicates that it was highly crystallized. The fringes of $\mathrm{d}=0.233 \mathrm{~nm}$ matched the (2 22 2) plane of $\mathrm{Co}_{3} \mathrm{O}_{4}$ nanoparticles, while the fringes of $\mathrm{d}=0.387 \mathrm{~nm}$ corresponded to the $\left(\begin{array}{lll}2 & 0 & 0\end{array}\right)$ plane of $\alpha-\mathrm{Bi}_{2} \mathrm{O}_{3}$, respectively. This confirmed that both $\mathrm{Bi}_{2} \mathrm{O}_{3}$ and $\mathrm{Co}_{3} \mathrm{O}_{4}$ phases coexisted in the $\mathrm{Bi}_{2} \mathrm{O}_{3}-\mathrm{Co}_{3} \mathrm{O}_{4}$ samples. The SAED pattern (Fig. 2c) obtained from the TEM showed well-defined rings and spots characteristic of well crystalline materials. Indexations of the diffraction pattern confirm the presence of both oxide phases in the catalyst.

The functional groups on the 50 wt. $\% \mathrm{Bi}_{2} \mathrm{O}_{3}-\mathrm{Co}_{3} \mathrm{O}_{4}$ composite and bare $\mathrm{Co}_{3} \mathrm{O}_{4}$ and $\mathrm{Bi}_{2} \mathrm{O}_{3}$ were analyzed by FTIR technique and the obtained FTIR spectra are shown in Fig. 3. The formation of $\mathrm{Co}_{3} \mathrm{O}_{4}$ spinel oxide in the composite catalyst was confirmed by the presence of two distinct absorption bands at 573 and $665 \mathrm{~cm}^{-1}$ which originate from the stretching vibrations of the cobalt-oxygen bonds. The low frequency band represents the vibrations of octahedrally coordinated $\mathrm{Co}^{3+}$ with oxygen in the spinel

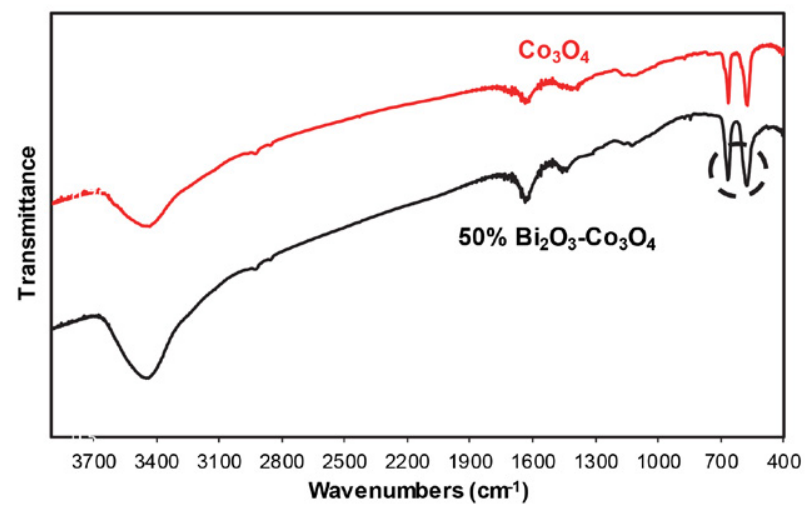

Fig. 3. FTIR spectra of the $50 \% \mathrm{Bi}_{2} \mathrm{O}_{3}-\mathrm{Co}_{3} \mathrm{O}_{4}, \mathrm{Co}_{3} \mathrm{O}_{4}$ and $\mathrm{Bi}_{2} \mathrm{O}_{3}$ lattice, while the high frequency band at $665 \mathrm{~cm}^{-1}$ can be assigned to the tetrahedral $\mathrm{Co}^{2+} \cdot 37,40$ The band at $847 \mathrm{~cm}^{-1}$ registered in the FTIR spectra of $\mathrm{Bi}_{2} \mathrm{O}_{3}-\mathrm{Co}_{3} \mathrm{O}_{4}$ and pure $\mathrm{Bi}_{2} \mathrm{O}_{3}$ is related to the vibration of $\mathrm{Bi}-\mathrm{O}$ bonds and the existence of $\alpha-\mathrm{Bi}_{2} \mathrm{O}_{3} \cdot{ }^{41} \mathrm{In}$ all samples, the absorption peaks at around 3445 and $1630 \mathrm{~cm}^{-1}$ correspond to the stretching and bending vibrations of hydroxyl groups and the adsorbed water molecules, respectively. ${ }^{42}$

XPS measurements were conducted to elucidate the surface characteristics of the prepared composite catalysts. Obvious photoelectron peaks due to $\mathrm{Co}, \mathrm{Bi}$ and $\mathrm{O}$ elements were detected in the survey spectrum of $50 \mathrm{wt} . \%$ $\mathrm{Bi}_{2} \mathrm{O}_{3}-\mathrm{Co}_{3} \mathrm{O}_{4}$ sample (Fig. 4a), confirming the presence of these elements on the surface of the catalyst. The curve fitting of Co $2 p$ spectrum is shown in Fig. $4 b$. The Co $2 p$ peaks at binding energies of $779.5 \mathrm{eV}$ and $794.2 \mathrm{eV}$ with satellite peak at $789.2 \mathrm{eV}$ are characteristics of $\mathrm{Co}^{3+}$ located at octahedral sites in the cubic spinel structure of $\mathrm{Co}_{3} \mathrm{O}_{4}$, while the peaks at $781.4 \mathrm{eV}$ and $796.4 \mathrm{eV}$ with satellite signal at $787.7 \mathrm{eV}$ are assigned to tetrahedral $\mathrm{Co}^{2+}$. The calculated atomic ratio of $\mathrm{Co}^{3+}$ to $\mathrm{Co}^{2+}$ was 1.93 , which is typical for $\mathrm{Co}_{3} \mathrm{O}_{4}$. The spin-orbit splitting of the Co $2 \mathrm{p}_{3 / 2}$ and Co $2 \mathrm{p}_{1 / 2}$ peaks signals was $15.1 \mathrm{eV}$, which is well consistent with the literature data of spinel $\mathrm{Co}_{3} \mathrm{O}_{4}$ and further confirmed that $\mathrm{Co}$ is present in the form of $\mathrm{Co}_{3} \mathrm{O}_{4}$ in composite catalysts. ${ }^{43}$ Two evident peaks observed at $162.7 \mathrm{eV}$ and $156.9 \mathrm{eV}$ in Bi $4 \mathrm{f} \mathrm{XPS} \mathrm{spectrum} \mathrm{of} \mathrm{(Fig.} \mathrm{4c)} \mathrm{are} \mathrm{assigned} \mathrm{to}$ $\mathrm{Bi} 4 \mathrm{f} 5 / 2$ and $\mathrm{Bi} 4 \mathrm{f} 7 / 2$ of $\mathrm{Bi}_{2} \mathrm{O}_{3}$, respectively. ${ }^{44}$ The high-resolution XPS spectrum of O 1s (Fig. 4d) shows two different peaks at 529.7 and $531.5 \mathrm{eV}$, which were assigned to the lattice oxide oxygen and surface hydroxyl groups, respectively. ${ }^{45}$ Quantitative analysis of the $\mathrm{O} 1 \mathrm{~s}$ spectra reveals that the relative content of the surface hydroxyl oxygen in the Co-Bi composite (22\% of the total oxygen) was twice higher than calculated for pure $\mathrm{Co}_{3} \mathrm{O}_{4}$. The availability of more hydroxyl groups on the surface of composite catalysts can promote the formation of surface $\mathrm{Co}-\mathrm{OH}$ complexes, which may favour the enhancement of the catalytic activity of Co catalysts for PMS activation.

\section{2. Catalytic Performance of $\mathrm{Bi}_{2} \mathrm{O}_{3}-\mathrm{Co}_{3} \mathrm{O}_{4}$ /PMS System on AO7 Oxidative Degradation}

The AO7 oxidative degradation was selected to evaluate the catalytic performance of the Co-Bi composite oxides for PMS activation. Initially, to confirm the occurrence of a catalytic reaction in the catalyst/PMS system, control experiments including adsorption tests and no catalyst addition were conducted. In comparison, the $\mathrm{Co}_{3} \mathrm{O}_{4}, \mathrm{Bi}_{2} \mathrm{O}_{3}$ and $\mathrm{Co}(\mathrm{II})$ ions (dissolved $\mathrm{Co}\left(\mathrm{NO}_{3}\right)_{2}$ ) were employed as references. Fig. 5 shows that no noticeable removal of AO7 was observed in the single use of PMS after $30 \mathrm{~min}$, indicating that PMS alone cannot produce free radicals to induce $\mathrm{AO} 7$ degradation. The as-prepared composite catalyst had no obvious adsorption toward AO7 

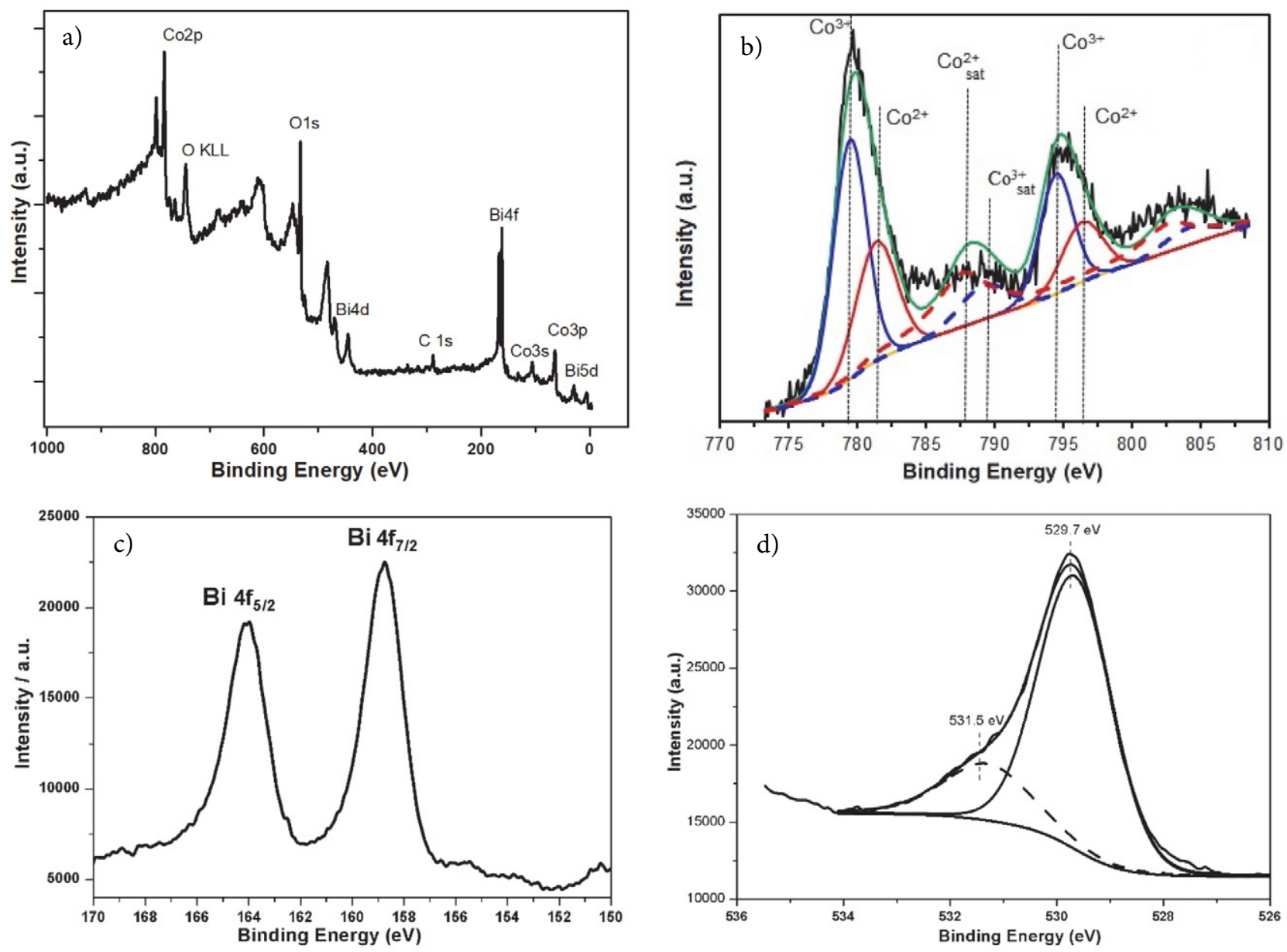

Fig. 4. XPS spectra of $50 \% \mathrm{Bi}_{2} \mathrm{O}_{3}-\mathrm{Co}_{3} \mathrm{O}_{4}$ sample: (a) wide survey, (b) Co 2p, (c) Bi 4 f and (d) O1s

and only less than $5 \%$ of the dye was removed in $30 \mathrm{~min}$. $\mathrm{PMS}$ also did not cause any decrease in the $\mathrm{AO} 7$ concentration when it was combined with pristine $\mathrm{Bi}_{2} \mathrm{O}_{3}$, indicating that $\mathrm{Bi}_{2} \mathrm{O}_{3}$ had low reactivity for PMS activation to degrade the dye. When bare $\mathrm{Co}_{3} \mathrm{O}_{4}$ was used as the catalyst for the activation of PMS to generate the active radicals, only $39 \%$ decolorization efficiency could be achieved within $12 \mathrm{~min}$, while a complete discoloration of the solution was attained for $90 \mathrm{~min}$. However, doping of $\mathrm{Bi}_{2} \mathrm{O}_{3}$ on $\mathrm{Co}_{3} \mathrm{O}_{4}$ greatly improved its catalytic performance for PMS activation and catalytic degradation of AO7. Specifically, after the addition of PMS, AO7 was completely degraded in 12 min using $\mathrm{Co}_{3} \mathrm{O}_{4}$ doped with 50 wt.\% $\mathrm{Bi}_{2} \mathrm{O}_{3}$, which should be attributed to the fast running radical-involved process. Since the contributions of adsorption and direct PMS oxidation on the AO7 removal are negligible, the catalytic oxidation over the composite catalyst can be considered as the main AO7 removal pathway. Furthermore, given that PMS is inefficient for AO7 degradation alone, the observed rapid first degradation stage in the degradation curve of $50 \% \mathrm{Bi}_{2} \mathrm{O}_{3}-\mathrm{Co}_{3} \mathrm{O}_{4}$ indicates that a large number of free radicals are generated upon the contact of the oxidant with the catalyst surface.

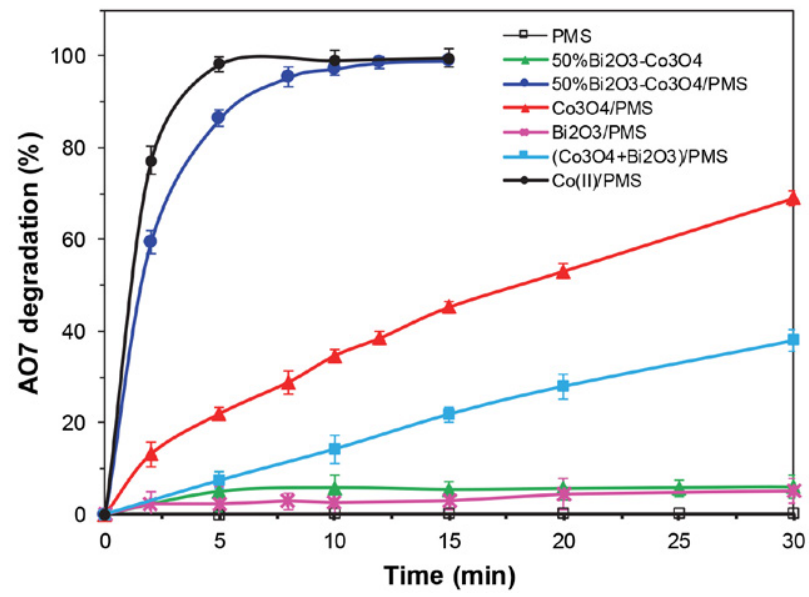

Fig. 5. Removal profiles of $A O 7$ in different systems. Reaction conditions: $[\mathrm{AO} 7]_{\mathrm{o}}=50 \mathrm{mg} / \mathrm{L} ;[\mathrm{PMS}] /[\mathrm{AO} 7]=6 ;[$ Catalyst $]=0.1 \mathrm{~g} / \mathrm{L}$; $\left[\mathrm{Co}^{2+}\right]=0.39 \mathrm{mg} / \mathrm{L} ;$ initial $\mathrm{pH}=3.04 ; \mathrm{T}=293 \mathrm{~K}$.

The superior catalytic activity of Co-Bi composite oxides relative to either $\mathrm{Co}_{3} \mathrm{O}_{4}$ or $\mathrm{Bi}_{2} \mathrm{O}_{3}$ suggests a synergistic effect of both oxides in the catalysts towards PMS activation for AO7 degradation. This synergetic coupling 
effect was further proved by degradation test conducted using the mechanical mixture of $\mathrm{Co}_{3} \mathrm{O}_{4}$ and $\mathrm{Bi}_{2} \mathrm{O}_{3}$ with a weight ratio of $1: 1$ as a catalyst. The results indicated that the catalytic performance of this mixture was evidently inferior to that of $50 \% \mathrm{Bi}_{2} \mathrm{O}_{3}-\mathrm{Co}_{3} \mathrm{O}_{4}$ composite under identical conditions. In fact, only $22 \% \mathrm{AO} 7$ removal in $15 \mathrm{~min}$ was achieved in the presence of the mechanical mixture, which is close to the average degradation value by $\mathrm{Co}_{3} \mathrm{O}_{4}$ and $\mathrm{Bi}_{2} \mathrm{O}_{3}$. Furthermore, a linear $\mathrm{AO} 7$ removal profile in a mechanical mixture/PMS system further evidences that activation of oxidant is the rate-limiting step of the oxidation process rather than the destruction of the dye molecules by radicals formed.

The catalytic performance of the most active composite $50 \% \mathrm{Bi}_{2} \mathrm{O}_{3}-\mathrm{Co}_{3} \mathrm{O}_{4}$ was slightly inferior to the $\mathrm{Co}(\mathrm{II})$ ions, used as a homogeneous catalyst for the activation of PMS at the same molar concentration of the solid catalyst. It could be speculated that the high weight percent of cobalt oxide in the catalyst may lead to significant leaching of Co ions in the solution. However, though the leaching process occurred during the degradation reaction, the amount of dissolved Co ions was detected to be up to $72 \mu \mathrm{g} / \mathrm{L}$ (Co leaching percent of $0.21 \%$ ) after the reaction was completed even in acidic conditions. This gives a reason to suggest that the homogeneous activation of PMS by leached $\mathrm{Co}$ (II) ions would be negligible and the heterogeneous pathway of PMS activation dominated in the $\mathrm{Bi}_{2} \mathrm{O}_{3}-\mathrm{Co}_{3} \mathrm{O}_{4} / \mathrm{PMS}$ system. The insignificant contribution of the homogeneous catalytic reaction promoted by dissolved Co ions was also confirmed by comparative experiments, in which leaching solution obtained upon complete removal of $\mathrm{AO} 7$ and filtering the catalyst was used to activate PMS for the oxidation of dye again. Less than $4 \% \mathrm{AO} 7$ was degraded in the leaching solution by PMS addition, which was much lower compared to the $\mathrm{Bi}_{2} \mathrm{O}_{3}-\mathrm{Co}_{3} \mathrm{O}_{4} / \mathrm{PMS}$ oxidation system, indicating that the main catalytic contribution is from the composite catalyst, not dissolved cobalt ions.

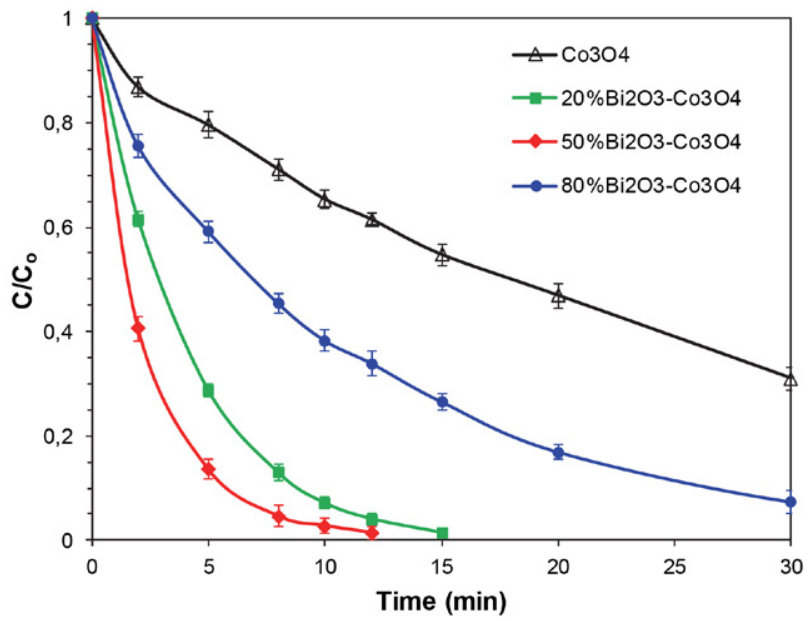

Fig. 6. $\mathrm{AO} 7$ catalytic degradation in $\mathrm{x}-\mathrm{Bi}_{2} \mathrm{O}_{3}-\mathrm{Co}_{3} \mathrm{O}_{4}$ composite/ PMS systems. Reaction conditions: $[\mathrm{AO} 7]_{\mathrm{o}}=50 \mathrm{mg} / \mathrm{L} ;[\mathrm{PMS}] /$ $[\mathrm{AO} 7]=6$; $[$ Catalyst $]=0.1 \mathrm{~g} / \mathrm{L} ;$ initial $\mathrm{pH}=3.04 ; \mathrm{T}=293 \mathrm{~K}$.
The $\mathrm{Bi}_{2} \mathrm{O}_{3}$ mass content in the composite catalysts had a noticeable influence on the catalytic activity of $\mathrm{Co}_{3} \mathrm{O}_{4}$ resulting in different $\mathrm{AO} 7$ degradation profiles. As seen from Fig. 6, the $\mathrm{AO} 7$ degradation efficiency considerably increased with the increase of $\mathrm{Bi}_{2} \mathrm{O}_{3}$ content up to $50 \%$. However, as the $\mathrm{Co}_{3} \mathrm{O}_{4}$ particles in the composites determined the PMS activation, the excessive amount of $\mathrm{Bi}_{2} \mathrm{O}_{3}$ (80 wt.\%) did not further promote the catalytic activity of $\mathrm{Co}_{3} \mathrm{O}_{4}$ and only $66 \%$ of dye was degraded for 12 min. Nevertheless, the catalytic efficiency of all $\mathrm{Bi}_{2} \mathrm{O}_{3}$ $\mathrm{Co}_{3} \mathrm{O}_{4}$ composites was higher than that of bare $\mathrm{Co}_{3} \mathrm{O}_{4}$.

Data of AO7 degradation with various catalysts in the PMS oxidation system were fitted well with the pseudo-first-order kinetic model (Fig. 7), indicating that the catalytic process is not controlled by the PMS activation step and radical generation. As seen from the inserted figure, the reaction rate constant $(k)$ of $\mathrm{AO} 7$ degradation increased considerably upon doping of $\mathrm{Co}_{3} \mathrm{O}_{4}$ with $\mathrm{Bi}_{2} \mathrm{O}_{3}$, demonstrating the positive effect of $\mathrm{Bi}_{2} \mathrm{O}_{3}$ addition for the faster PMS activation. Specifically, the kinetic constant for $50 \% \mathrm{Bi}_{2} \mathrm{O}_{3}-\mathrm{Co}_{3} \mathrm{O}_{4}$ is ca. 9.5 times higher than those of $\mathrm{Co}_{3} \mathrm{O}_{4}$ although the specific surface area of the composite $\left(28.12 \mathrm{~m}^{2} / \mathrm{g}\right)$ was only slightly lower than that of the pure cobalt oxide $\left(30.1 \mathrm{~m}^{2} / \mathrm{g}\right)$. This result indicates that some other factors besides the specific surface area played much more important roles in the activation process.

The much better performance for PMS activation ex-

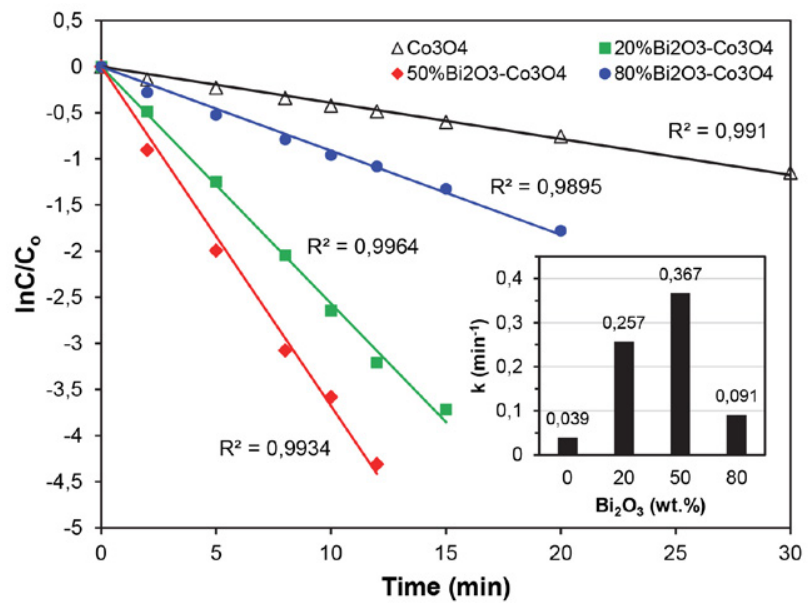

Fig. 7. First-order kinetic fitting of the AO7 degradation curves. Reaction conditions: $[\mathrm{AO} 7]_{\mathrm{o}}=50 \mathrm{mg} / \mathrm{L} ;[\mathrm{PMS}] /[\mathrm{AO} 7]=6$; [Catalyst $]$ $=0.1 \mathrm{~g} / \mathrm{L} ;$ initial $\mathrm{pH}=3.04 ; \mathrm{T}=293 \mathrm{~K}$.

hibited by $\mathrm{Bi}_{2} \mathrm{O}_{3}-\mathrm{Co}_{3} \mathrm{O}_{4}$ hybrids than the bare cobalt oxide could be attributed to the increased basicity of the $\mathrm{Co}_{3} \mathrm{O}_{4}$ surface after $\mathrm{Bi}_{2} \mathrm{O}_{3}$ modification resulting in a more hydroxylated surface that facilitates the decomposition of PMS to reactive radicals. This suggestion was well in accordance with the point of zero charge $\left(\mathrm{pH}_{\mathrm{pzc}}\right)$ measurements. The $\mathrm{pH}$ at which the curve $\mathrm{pH}($ final $)=\mathrm{pH}$ (initial) crosses the dashed line, obtained without the addition of a catalyst (see Fig. 8) is taken as the $\mathrm{pH}_{\mathrm{pzc}}$ of the given cata- 


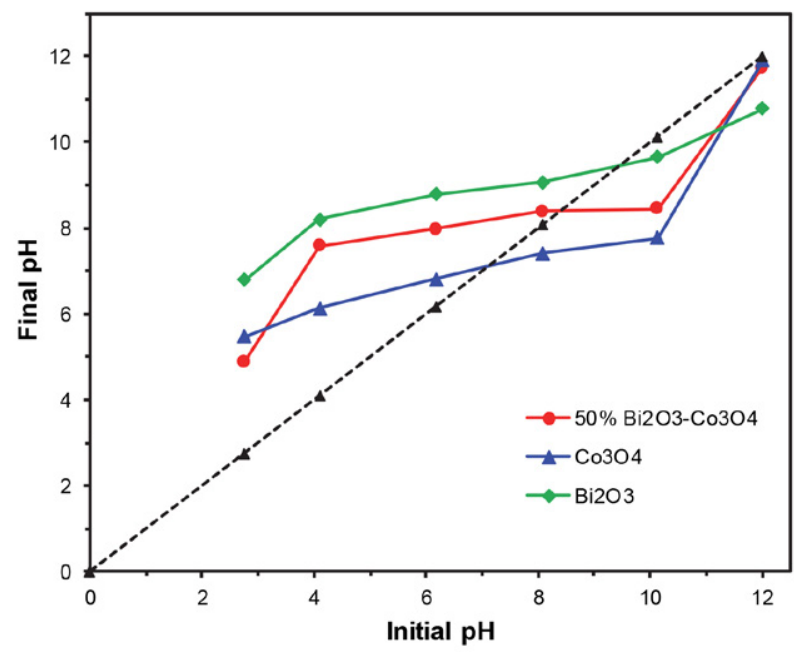

Fig. 8. $\mathrm{pH}$ drift method to obtain the $\mathrm{pH}_{\mathrm{pzc}}$ of the as-prepared oxide systems. The dashed line applies to the system without added catalyst

lyst. As given in Fig. 8, the $\mathrm{pH}_{\mathrm{pzc}}$ value of $\mathrm{Co}_{3} \mathrm{O}_{4}$ increased from 7.1 to 8.4 after the doping with $\mathrm{Bi}_{2} \mathrm{O}_{3}$, indicating for the enhanced content of hydroxyl groups on the surface of the composite catalyst. Such difference between the surface charge of the $\mathrm{Co}_{3} \mathrm{O}_{4}$ and $\mathrm{Bi}_{2} \mathrm{O}_{3}-\mathrm{Co}_{3} \mathrm{O}_{4}$ is consistent with the XPS results that show a higher content of the surface hydroxyl oxygen in the Co-Bi composite than that in $\mathrm{Co}_{3} \mathrm{O}_{4}$.

Fig. 9 depicts the UV-vis spectral changes of $\mathrm{AO} 7$ in solution during the catalytic degradation in the presence of most active $50 \% \mathrm{Bi}_{2} \mathrm{O}_{3}-\mathrm{Co}_{3} \mathrm{O}_{4}$ composite. In the visible region, the spectrum of initial $\mathrm{AO} 7$ solution exhibits a main band with a maximum located at $486 \mathrm{~nm}$ and a shoulder at $430 \mathrm{~nm}$, corresponding to the $\mathrm{n}-\pi^{*}$ transitions of the hydrazone form and azo form of the dye, respectively, and are due to the chromophore-containing azo-linkage. ${ }^{46}$ The other two bands in the ultraviolet region, located at 230 and $310 \mathrm{~nm}$, are ascribed to the $\pi-\pi^{\star}$ transitions in the benzene and naphthalene rings of $\mathrm{AO} 7$, respectively. It is apparent that the major band at $486 \mathrm{~nm}$ declined rapidly as the reaction progressed and finally disappeared after $12 \mathrm{~min}$, indicating the facile break-up of the azo-linkage. In parallel, the intensity of the absorbance bands in the UV region is also reduced, implying for concomitant destruction of the conjugated p-system of the dye molecule. Meanwhile, a new absorption band around $255 \mathrm{~nm}$ appeared concurrently with the decay in the visible region, indicating that a new structure unit is formed from chromophore cleavage. This band was generated at the very beginning of reaction (even at $2 \mathrm{~min}$ ) and after discoloration of the solution at $12 \mathrm{~min}$, its intensity starts to drop slowly, which proves that an intermediate formed is further also degraded. 1,2-naphthoquinone was identified to contribute to the peak at $255 \mathrm{~nm}$ by comparing the spectra of the reaction mixture and a standard solution of 1,2-naphthoquinone.

The degradation intermediates of $\mathrm{AO} 7$ were also monitored by HPLC analysis. Fig. 10 shows chromato-

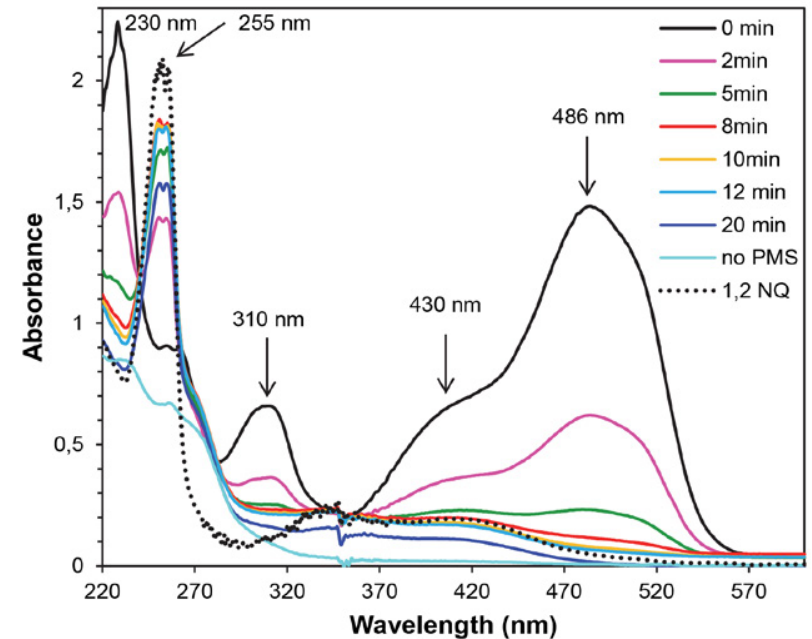

Fig. 9. UV-vis spectra of $\mathrm{AO} 7$ catalytic degradation on $50 \% \mathrm{Bi}_{2} \mathrm{O}_{3}$ $\mathrm{Co}_{3} \mathrm{O}_{4}$. Reaction conditions: $[\mathrm{AO} 7]_{\mathrm{o}}=50 \mathrm{mg} / \mathrm{L} ;[\mathrm{PMS}] /[\mathrm{AO} 7]=6$; $[$ Catalyst $]=0.1 \mathrm{~g} / \mathrm{L} ;$ initial $\mathrm{pH}=3.04 ; \mathrm{T}=293 \mathrm{~K}$.

grams of the $\mathrm{AO} 7$ solution before and in the course of degradation catalyzed by the $50 \% \mathrm{Bi}_{2} \mathrm{O}_{3}-\mathrm{Co}_{3} \mathrm{O}_{4}$ together with the chromatogram of a standard solution, containing the expected main intermediates from $\mathrm{AO} 7$ degradation. The chromatogram of the initial AO7 solution shows a single peak with a retention time $t_{R}$ at $12.75 \mathrm{~min}$, whose intensity dramatically declined when the reaction proceeded and almost disappeared after $10 \mathrm{~min}$. Concurrently, six intermediates were generated, identified as 4-hydroxybenzenesulfonic acid $\left(t_{R}\right.$ at $\left.2.6 \mathrm{~min}\right)$, phthalic anhydride $\left(t_{R}\right.$ at 7.08 min), phthalimide ( $t_{R}$ at $\left.8.1 \mathrm{~min}\right), 1,2$-naphthoquinone $\left(t_{R}\right.$ at $12.3 \mathrm{~min})$, coumarin $\left(t_{R}\right.$ at $\left.13.3 \mathrm{~min}\right)$, and unidentified product with $t_{R}$ at $11.2 \mathrm{~min}$. The intermediate product 1,2-naphthoquinone distinguished from the other ones by its highest intensity during the whole process, as well as by

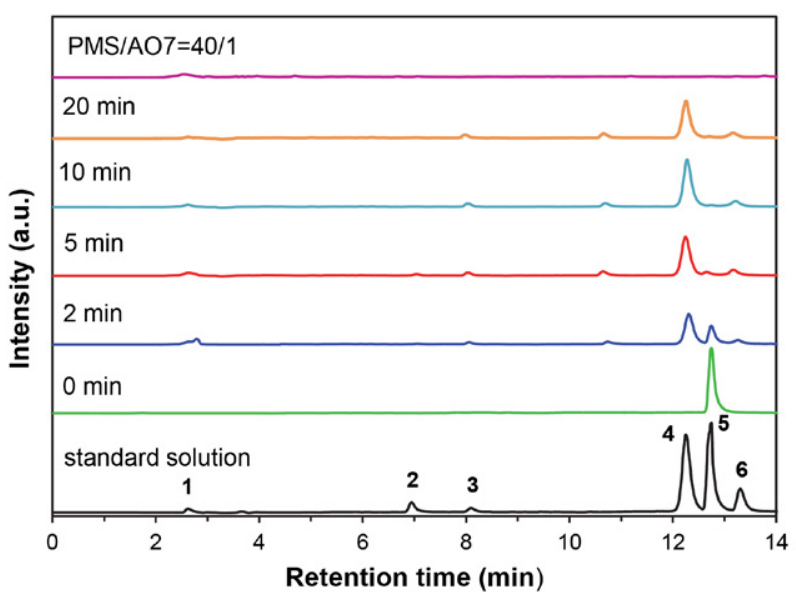

Fig. 10. HPLC chromatograms of $\mathrm{AO} 7$ during catalytic oxidation on $50 \% \mathrm{Bi}_{2} \mathrm{O}_{3}-\mathrm{Co}_{3} \mathrm{O}_{4}$ and standard solution [(1) 4-hydroxybenzenesulfonic acid, (2) phthalic anhydride, (3) phthalimide, (4) 1,2-naphthoquinone, (5) AO7, (6) coumarin]. Reaction conditions: $[\mathrm{AO} 7]_{\mathrm{o}}=50 \mathrm{mg} / \mathrm{L} ;[\mathrm{PMS}] /[\mathrm{AO} 7]=6 ;[$ Catalyst $]=0.1 \mathrm{~g} / \mathrm{L} ;$ initial $\mathrm{pH}=3.04 ; \mathrm{T}=293 \mathrm{~K}$. 
the most well-defined intensity changes. It gradually accumulated up to $10 \mathrm{~min}$ and then starts to decrease as evidenced by UV-vis analysis as well. However, the disappearance of all peaks when raising the $\mathrm{PMS} / \mathrm{AO} 7$ molar ratio to 40:1, corresponding to the stoichiometric one for mineralization of $\mathrm{AO}$, suggests that the generated intermediates were finally mineralized.

\section{3. Effect of Reaction Variables on AO7 Degradation}

Further kinetic studies were carried out using the most active $50 \% \mathrm{Bi}_{2} \mathrm{O}_{3}-\mathrm{Co}_{3} \mathrm{O}_{4}$ catalyst to investigate the effects of several key parameters, namely the catalyst dosage, $\mathrm{PMS}$ concentration, initial solution $\mathrm{pH}$, and temperature on the $\mathrm{AO} 7$ degradation.

\section{2. 1. Effect of Catalyst Amount}

Fig.11a depicts the degradation kinetics of $\mathrm{AO} 7$ by PMS with different $\mathrm{Bi}_{2} \mathrm{O}_{3}-\mathrm{Co}_{3} \mathrm{O}_{4}$ dosages in the range of $0.05 \mathrm{~g} / \mathrm{L}-0.3 \mathrm{~g} / \mathrm{L}$. Apparently, increasing the amount of catalyst resulted in an increased degradation rate for $\mathrm{AO} 7$, confirming the crucial role of the catalyst for the generation of the radicals as well as indicating that the surface reaction is the rate-limiting step. In comparison, at catalyst loading of $0.05 \mathrm{~g} / \mathrm{L},{ }^{3} \mathrm{AO} 7$ removal efficiency could reach $100 \%$ after $20 \mathrm{~min}$, whereas only 5 minutes are needed for complete dye degradation in the presence of $0.3 \mathrm{~g} / \mathrm{L}$ catalyst. Accordingly, the first-order rate constant $k$ increased from 0.1804 to $0.839 \mathrm{~min}^{-1}$ as observed in Fig $11 \mathrm{~b}$. Besides, the degradation rate constants present a linear trend as a function of catalyst dosage at the same PMS concentration, thereby implying that there is no competition between the dye and PMS for the active sites on the catalyst surface. The inset in Fig. 11 presenting the kinetic fitting curves confirms that the AO7 degradation follows a firstorder kinetics model. The continuous increase of the $\mathrm{AO} 7$ degradation rate with catalyst load can be attributed to the more surface active sites for PMS activation, thereby resulting in a faster generation of reactive radical species and consequently in an enhancement of the reaction rate.

\section{2. 2. Effect of PMS Concentration}

As illustrated in Fig. 12, the AO7 catalytic degradation on $\mathrm{Bi}_{2} \mathrm{O}_{3}-\mathrm{Co}_{3} \mathrm{O}_{4}$ also showed a positive dependence on the PMS dosage (in terms of PMS/AO7 molar ratio). At the lowest [PMS/AO7] ratio of 1:1 complete removal of $\mathrm{AO} 7$ was not achieved due to a lack of sufficient oxidant amount. However, as the [PMS]/[AO7] ratio was increased from 1:1 to 6:1, the AO7 removal efficiency significantly increased from $66.5 \%$ to $100 \%$ and the degradation rate constant rapidly rises from 0.113 to $0.367 \mathrm{~min}^{-1}$ (inset of Fig. 12). However, further increase of the [PMS]/[AO7] molar ratio to $12: 1$ induced only a slight enhancement in

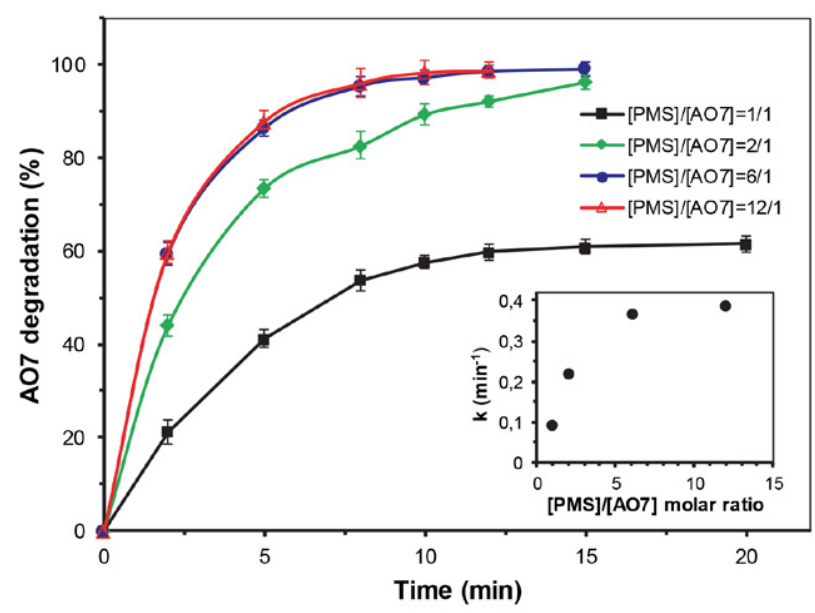

Fig. 12. Effect of PMS dosages on $\mathrm{AO} 7$ degradation and $\mathrm{AO} 7$ degradation kinetics (inset) by $50 \% \mathrm{Bi}_{2} \mathrm{O}_{3}-\mathrm{Co}_{3} \mathrm{O}_{4} / \mathrm{PMS}$ oxidation system. Reaction conditions: $50 \mathrm{mg} / \mathrm{L}$; [Catalyst] $=0.1 \mathrm{~g} / \mathrm{L}$; initial $\mathrm{pH}=$ 3.04; $\mathrm{T}=293 \mathrm{~K}$.
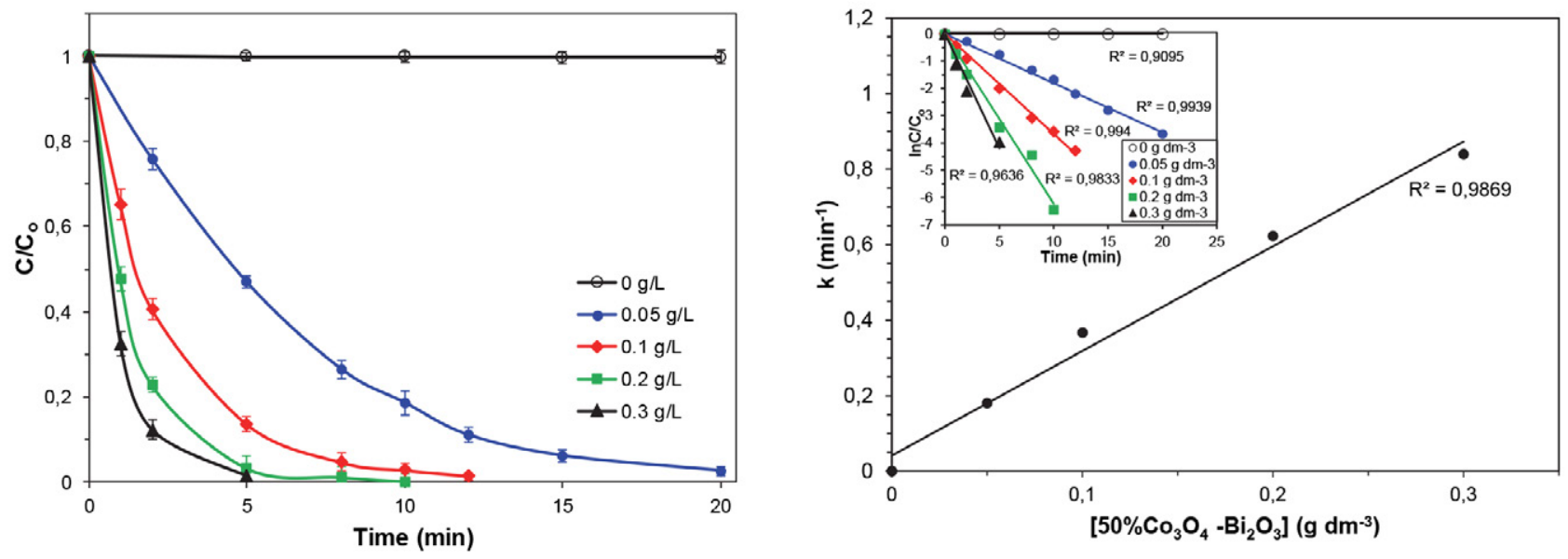

Fig. 11. Catalytic performance of $50 \% \mathrm{Bi}_{2} \mathrm{O}_{3}-\mathrm{Co}_{3} \mathrm{O}_{4}$ at various dossages in the presence of PMS and AO7: (a) AO7 degradation; (b) AO7 degradation kinetics. Reaction conditions: $[\mathrm{AO} 7]_{\mathrm{o}}=50 \mathrm{mg} / \mathrm{L} ;[\mathrm{PMS}] /[\mathrm{AO} 7]=6$; initial $\mathrm{pH}=3.04 ; \mathrm{T}=293 \mathrm{~K}$. 
the $\mathrm{AO} 7$ degradation rate. Being the source of active radicals, an increase of the PMS dosage promotes the generation of more radicals, which accounts for the rapid AO7 degradation. However, at high PMS concentrations, the fixed amount of catalyst gradually became the limiting factor controlling the generation of radicals so that the radical yield was almost independent of PMS dosage. Furthermore, the unreacted PMS behaves as the quencher of active radicals according to the following reactions: ${ }^{47}$

$$
\begin{aligned}
& \mathrm{SO}_{4}^{-}+\mathrm{HSO}_{5}^{-} \rightarrow \mathrm{SO}_{5}^{-}+\mathrm{HSO}_{4}^{-} \\
& \mathrm{OH}+\mathrm{HSO}_{5}^{-} \rightarrow \mathrm{SO}_{5}^{-}+\mathrm{H}_{2} \mathrm{O}
\end{aligned}
$$

\section{2. 3. Effect of $\mathrm{pH}$}

Solution $\mathrm{pH}$ plays a significant role in the degradation process due to its influence on the surface charge of the catalyst as well as the existing form of PMS in solution. As the natural wastewater has variable acidity, it is important to investigate the influence of $\mathrm{pH}$ on the degradation efficiency of $\mathrm{AO} 7$ in $50 \% \mathrm{Bi}_{2} \mathrm{O}_{3}-\mathrm{Co}_{3} \mathrm{O}_{4} / \mathrm{PMS}$ system. Fig. 13a shows that the efficient catalytic degradation of $\mathrm{AO} 7$ in this system is applicable to a wide $\mathrm{pH}$ range of 3.04 to 9.3, which covers the common $\mathrm{pH}$ of natural water and wastewater. Moreover, the discoloration of $\mathrm{AO} 7$ solution was complete in a short period of time (12 $\mathrm{min})$ even at alkaline conditions. The surface of $\mathrm{Bi}_{2} \mathrm{O}_{3}-\mathrm{Co}_{3} \mathrm{O}_{4}$ particles is positively charged when the solution $\mathrm{pH}$ is less than 8.4 $\left(\mathrm{pH}_{\mathrm{pzc}}\right.$ of the sample). According to the $\mathrm{pK}_{\mathrm{a}}$ values of PMS $\left(\mathrm{pK}_{\mathrm{a} 1}<0, \mathrm{pK}_{\mathrm{a} 2}=9.4^{47}\right)$, PMS mainly exists in the form of $\mathrm{HSO}_{5}{ }^{-}$in the solution $\mathrm{pH}$ range of 4.0 to 8.5. Therefore, PMS and catalyst surface were oppositely charged within this $\mathrm{pH}$ range, which facilitates their interaction through the electrostatic attractive forces. Although electrostatic repelling forces between the negatively-charged catalyst's surface and $\mathrm{HSO}_{5}{ }^{-}$are prominent at $\mathrm{pH} 9.3$, slightly faster initial discoloration kinetics was observed at this $\mathrm{pH}$, suggesting that base activation of $\mathrm{PMS}$ by $\mathrm{NaOH}$ (used to adjust $\mathrm{pH}$ to 9.3) may also take effect in basic conditions. Furthermore, the different UV-vis absorption spectrum of the solution after the degradation process at $\mathrm{pH} 9.3 \mathrm{imply}$ for a different AO7 degradation mechanism (Fig. 13b). Specifically, the new peak at $255 \mathrm{~nm}$ did not appear in the spectra as well as a residual absorbance at 228 and $310 \mathrm{~nm}$ was still observed even when the reaction was completed, indicating that some intermediates generated from the fragmentation of the azo links still contain benzoic and naphthalene rings.

Meanwhile, $\mathrm{pH}$ variation during the $\mathrm{AO} 7$ degradation process was also monitored. As shown in Fig. 13c, the solution $\mathrm{pH}$ with an initial value of 3.04 maintained almost unchanged over time but decreased when the initial $\mathrm{pH}$ was 7.06 and reached around $\mathrm{pH} 3.4$ within 8 min reaction. This phenomenon could be attributed to the release of protons along with PMS decomposition and the
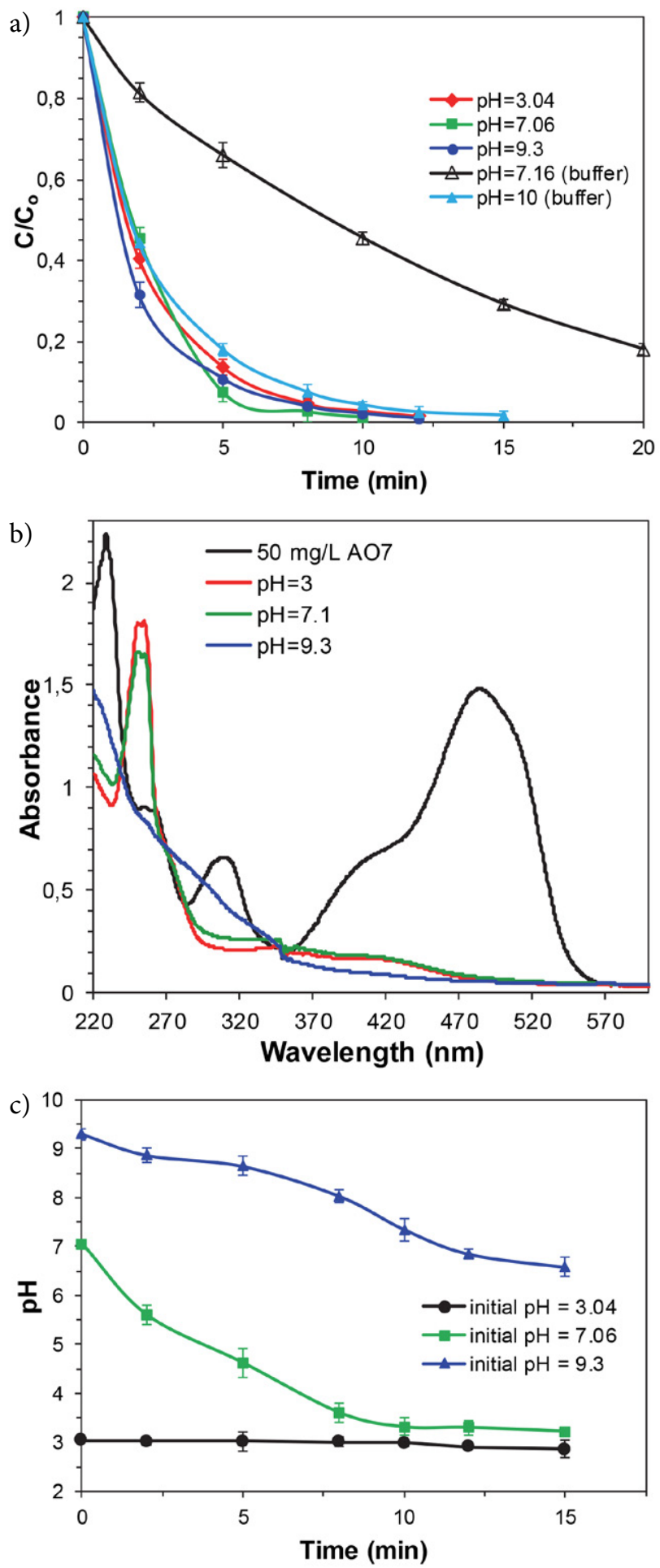

Fig. 13. Performance of $50 \% \mathrm{Bi}_{2} \mathrm{O}_{3}-\mathrm{Co}_{3} \mathrm{O}_{4}$ for $\mathrm{AO} 7$ degradation with PMS at different initial pHs: (a) AO7 degradation; (b) UV-vis spectra of the $\mathrm{AO} 7$ aqueous solution at $12 \mathrm{~min}$; (c) Changes of $\mathrm{pH}$ over time in the case of different initial $\mathrm{pH}$ values. Reaction conditions : $[\mathrm{AO} 7]_{\mathrm{o}}=50 \mathrm{mg} / \mathrm{L} ;[\mathrm{PMS}] /[\mathrm{AO} 7]=6 ;[$ Catalyst $]=0.1 \mathrm{~g} / \mathrm{L} ; \mathrm{T}=293 \mathrm{~K}$.

formation of acidic intermediate products during the $\mathrm{AO} 7$ degradation process. However, under basic conditions, the $\mathrm{pH}$ value only slightly decreased as the reaction went on 
and finally kept to nearly neutral probably due to the high initial concentration of $\mathrm{OH}^{-}(2.0 \mathrm{mM})$ which prevented a significant decrease in the $\mathrm{pH}$.

The effect of buffer solutions on the AO7 removal efficiency was also evaluated. Accordingly with Fig. 13a, the degradation rate of $\mathrm{AO} 7$ was considerably decreased when the initial solution was buffered to 7.16 using $0.004 \mathrm{M}$ phosphate buffer (in the forms of $\mathrm{H}_{2} \mathrm{PO}_{4}{ }^{-}$and $\mathrm{HPO}_{4}{ }^{2-}$ ). In the buffered system, complete $\mathrm{AO} 7$ degradation was achieved in $50 \mathrm{~min}$ and the rate constant decreased 5.3 times compared with the experiment at an initial $\mathrm{pH}$ of 7.06 adjusted with $\mathrm{NaOH}$. The observed retarding effect could be due to the quenching of active radicals generated from PMS catalytic decomposition by phosphate anions in the solution. ${ }^{48,49}$ In contrast, the oxidation of $\mathrm{AO} 7$ was quite significant when $\mathrm{NaHCO}_{3} / \mathrm{NaOH}$ buffer used to adjust the initial pH to 10 (Fig. 13a). Although the surface of $\mathrm{Bi}_{2} \mathrm{O}_{3}-\mathrm{Co}_{3} \mathrm{O}_{4}$ is negatively charged at $\mathrm{pH}$ higher than 8.4 and PMS existed mostly in the form of $\mathrm{SO}_{5}{ }^{2-}$ at $\mathrm{pH}$ range of 9.5-10.5, the AO7 degradation rate and efficiency were comparable to that attained in an acidic medium. Therefore, it could be speculated that along with heterogeneous activation of PMS, the active species may also be generated as a result of anion decomposition of PMS which, due to its unsymmetric structure, can easily be attacked by nucleophile such as $\mathrm{HCO}_{3}{ }^{-50}$ Besides, base activation of PMS by $\mathrm{NaOH}$ was also enhanced at $\mathrm{pH} 10$.

\section{2. 4. Effect of Temperature}

The effect of reaction temperature on PMS activation by $50 \% \mathrm{Bi}_{2} \mathrm{O}_{3}-\mathrm{Co}_{3} \mathrm{O}_{4}$ for $\mathrm{AO} 7$ degradation was also studied. Considering the observations in Fig. 14, an increase in temperature had a positive effect on $\mathrm{AO} 7$ removal rate due to accelerating the decomposition of PMS into active radicals under thermal activation. ${ }^{51}$ As the temperature increased from 18 to $38{ }^{\circ} \mathrm{C}$, the decolorization kinetics was remarkably enhanced and the rate constant value increased from 0.283 to $0.530 \mathrm{~min}^{-1}$. At $18{ }^{\circ} \mathrm{C}, \mathrm{AO} 7$ was completely destroyed within $15 \mathrm{~min}$, whereas removal reached up to $100 \%$ at $38^{\circ} \mathrm{C}$ in just $7 \mathrm{~min}$. The temperature dependence of the rate constant was further used to determine activation energy $\left(E_{\mathrm{a}}\right)$ by plotting $\ln k$ against $1 / T$ according to the Arrhenius equation (inset of Fig. 14). The calculated $E_{\mathrm{a}}$ value for $\mathrm{AO} 7$ degradation with $50 \% \mathrm{Bi}_{2} \mathrm{O}_{3}-\mathrm{Co}_{3} \mathrm{O}_{4}$ as a catalyst was $22.7 \mathrm{~kJ} \mathrm{~mol}^{-1}$, whereas that obtained in the presence of pristine $\mathrm{Co}_{3} \mathrm{O}_{4}$ was $35.5 \mathrm{~kJ} \mathrm{~mol}^{-1}$. Both $E_{\mathrm{a}}$ values are higher than the activation energy of diffusion-controlled reactions $\left(10-13 \mathrm{~kJ} \mathrm{~mol}^{-1}\right)$, revealing that the $\mathrm{AO} 7$ catalytic degradation process was controlled by the rate of chemical reaction on the catalyst surface rather than mass transfer rate. The lower $E_{\mathrm{a}}$ value obtained for the $50 \% \mathrm{Bi}_{2} \mathrm{O}_{3^{-}}$ $\mathrm{Co}_{3} \mathrm{O}_{4} / \mathrm{PMS}$ system was in agreement with its best $\mathrm{AO} 7$ degradation efficiency and confirmed that $\mathrm{Bi}_{2} \mathrm{O}_{3}$ had a great influence on the $\mathrm{Co}_{3} \mathrm{O}_{4}$ catalytic reactivity for PMS activation.

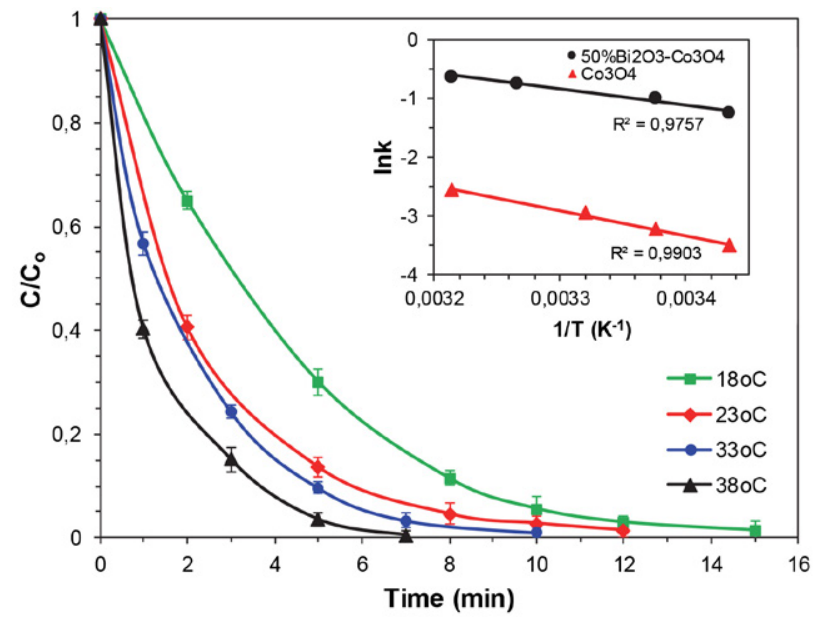

Fig. 14. Effect of reaction temperature on $\mathrm{AO} 7$ degradation by $50 \%$ $\mathrm{Bi}_{2} \mathrm{O}_{3}-\mathrm{Co}_{3} \mathrm{O}_{4} / \mathrm{PMS}$ oxidation system. Reaction conditions: [AO7] $=50 \mathrm{mg} / \mathrm{L} ;[\mathrm{PMS}] /[\mathrm{AO} 7]=6 ;[$ Catalyst $]=0.1 \mathrm{~g} / \mathrm{L} ;$ initial $\mathrm{pH}=3.04$.

\section{2. 5. Identification of Reactive Species}

Selective radical quenching tests were performed to identify the dominating radical species formed during PMS activation by the catalyst and accounting for the AO7 degradation. The activation of PMS by metal-containing catalysts might produce sulfate $\left(\mathrm{SO}_{4}{ }^{-}\right)$, hydroxyl $(\cdot \mathrm{OH})$, and peroxy-sulfate $\left(\mathrm{SO}_{5}{ }^{-}\right)$radicals. ${ }^{52}$ The $\mathrm{AO} 7$ degradation by $\mathrm{SO}_{5}{ }^{--}$could be neglected because of its much lower oxidation potential $\left(E^{\mathrm{o}}=0.81 \mathrm{~V}\right) .{ }^{53}$

Various radical scavengers were tested in the reaction solution including ethanol (EtOH), tert-butyl alcohol (TBA), KI, and ascorbic acid and the results are presented in Fig. 15. With the addition of $0.02 \mathrm{M}$ ascorbic acid, the degradation of $\mathrm{AO} 7$ is almost completely inhibited and the degradation rate is the same as observed by the removal of dye without PMS. Since the ascorbic acid is considered to be a strong radical scavenger, it can be concluded that the radical pathway mechanism of $\mathrm{AO} 7$ degradation is involved in the $50 \% \mathrm{Bi}_{2} \mathrm{O}_{3}-\mathrm{Co}_{3} \mathrm{O}_{4}$ activated PMS system. To evaluate the contribution of $\mathrm{SO}_{4}{ }^{-{ }^{-}}$and $\bullet \mathrm{OH}$ to $\mathrm{AO} 7$ degradation, $\mathrm{EtOH}$ and TBA were used as radical scavengers. $\mathrm{EtOH}$ (containing $\alpha$-hydrogen) can readily react with both radicals at high and comparable rates $\left(k_{\cdot \mathrm{OH}}: 1.2-2.8 \times 10^{9}\right.$ mol L ${ }^{-1} \mathrm{~s}^{-1}$; $\left.k_{\text {SO4.: }}: 1.6-7.7 \times 10^{7} \mathrm{~mol} \mathrm{~L}^{-1} \mathrm{~s}^{-1}\right)$, whereas the scavenging of $\bullet \mathrm{OH}$ by TBA (without a-hydrogen) is much faster than $\mathrm{SO}_{4}{ }^{--}\left(k_{\cdot \circ \mathrm{OH}}: 3.8-7.6 \times 10^{8} \mathrm{~mol} \mathrm{~L}^{-1} \mathrm{~s}^{-1} ; k_{\mathrm{SO} 4 .-}: 4-\right.$ $\left.9.1 \times 10^{5} \mathrm{~mol} \mathrm{~L}^{-1} \mathrm{~s}^{-1}\right) \cdot{ }^{14,53,54}$ As observed in Fig. 15, the AO7 removal kinetics was slightly affected by the presence of TBA, and the kinetic constant of AO7 degradation decreased from $0.367 \mathrm{~min}^{-1}$ (with no scavenger) to 0.271 $\mathrm{min}^{-1}$ at a TBA/PMS ratio of 2000/1. On the other hand, the addition of EtOH resulted in decreasing $\mathrm{AO} 7$ removal to $76.4 \%$ at $12 \mathrm{~min}$ and reaching final removal efficiency of $85.2 \%$ at $20 \mathrm{~min}$ when the PMS was exhausted. Accordingly, around a 3 -fold decrease of the reaction rate constant value was observed due to the inhibitory effect of ethanol. 


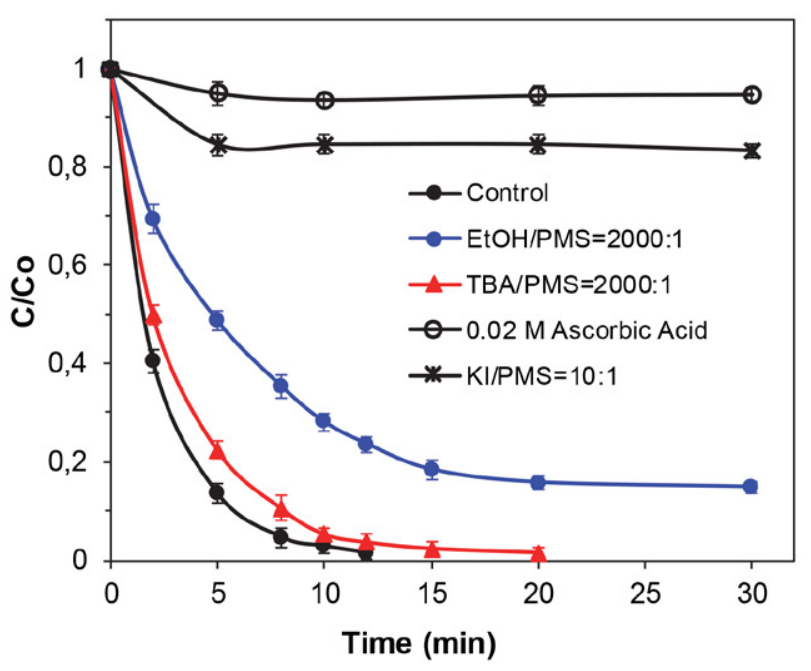

Fig. 15. Effect of radical scavengers on $\mathrm{AO} 7$ degradation. Reaction conditions: $[\mathrm{AO} 7]_{\mathrm{o}}=50 \mathrm{mg} / \mathrm{L} ;[\mathrm{PMS}] /[\mathrm{AO} 7]=6$; $[$ Catalyst $]=0.1$ $\mathrm{g} / \mathrm{L} ;$ initial $\mathrm{pH}=3.04 ; \mathrm{T}=293 \mathrm{~K}$.

These results suggest that in the $\mathrm{Bi}_{2} \mathrm{O}_{3}-\mathrm{Co}_{3} \mathrm{O}_{4} / \mathrm{PMS}$ system the major radical species involved in the attack of $\mathrm{AO} 7$ are sulfate radicals. A probable reason for the relative slight inhibitory effects of both alcohols might be that $\mathrm{EtOH}$ and TBA being highly hydrophilic prefer to quench free radicals in solution rather than reacting radicals in catalyst surface. ${ }^{55}$ Furthermore, a complete suppression of the AO7 degradation was observed upon the addition of KI even at a KI/PMS ratio of 10/1. Since iodine ions are considered as scavenging agents for surface-bound radicals in advanced oxidation processes, it may be concluded that $\mathrm{SO}_{4}{ }^{-{ }^{-}}$radicals on the surface play a dominant role in the AO7 degradation in $\mathrm{Bi}_{2} \mathrm{O}_{3}-\mathrm{Co}_{3} \mathrm{O}_{4} / \mathrm{PMS}$ oxidation system.

\section{Conclusions}

In this work, $\mathrm{Bi}_{2} \mathrm{O}_{3}-\mathrm{Co}_{3} \mathrm{O}_{4}$ composites with different content were synthesized using a facile co-precipitation method and applied as catalysts for the degradation of AO7 dye by activating PMS via a radical pathway. The XRD and HRTM characterization confirmed the coexistence of $\mathrm{Bi}_{2} \mathrm{O}_{3}$ and $\mathrm{Co}_{3} \mathrm{O}_{4}$ phases in the $\mathrm{Bi}_{2} \mathrm{O}_{3}-\mathrm{Co}_{3} \mathrm{O}_{4}$ composites. Compared to bare $\mathrm{Co}_{3} \mathrm{O}_{4}$, the as-prepared composite catalysts exhibited superior performance in the heterogeneous activation of PMS to generate radical species and thus induced the rapid degradation of $\mathrm{AO} 7$ over a wide $\mathrm{pH}$ range ( $\mathrm{pH} 3-10)$. In the presence of the most active 50 wt. $\% \mathrm{Bi}_{2} \mathrm{O}_{3}-\mathrm{Co}_{3} \mathrm{O}_{4}$, an initial $\mathrm{AO} 7$ concentration of $50 \mathrm{mg} / \mathrm{L}$ was completely removed within $12 \mathrm{~min}$, and the rate constant is around 9.5 - fold as compared with bare $\mathrm{Co}_{3} \mathrm{O}_{4}$. The enhanced PMS-activating ability of the $\mathrm{Bi}_{2} \mathrm{O}_{3}$ $\mathrm{Co}_{3} \mathrm{O}_{4}$ composites was attributed to the increased hydroxyl oxygen content on their surface due to the presence of basic $\mathrm{Bi}$ oxide, which facilitates the formation of surface $\mathrm{Co}-\mathrm{OH}$ complexes and promotes the activation of PMS.
The increase of catalyst dosage, PMS concentration and temperature leads to enhancement of the AO7 removal efficiency, however increasing the catalyst loading is most beneficial. Based on the chemical scavenger study, sulfate radicals were identified as the major reactive species formed by the catalyst/PMS interaction and responsible for AO7 degradation. The synthesized catalytic systems could be regarded as promising heterogeneous catalysts for the degradation of organic pollutants in water through a sulfate radical approach.

\section{Acknowledgements}

Authors gratefully acknowledge financial support by the Centre for Competence»Personalized Innovative Medicine, PERIMED (EU Programme "Science and Education for Smart Growth” grant BG05M2OP001-1.002-0005$\mathrm{C} 01)$.

\section{References}

1. B. D. Tony, D. Goyal, S. Khanna, Int. Biodeter. Biodegr. 2009, 63, 462-469. DOI:10.1016/j.ibiod.2009.01.003

2. R. D. Ambashta, M. Sillanpää, J. Hazard. Mater. 2010, 180, 38-49. DOI:10.1016/j.jhazmat.2010.04.105

3. S. Eftekthari, A. Habibi-Yangjeh, Sh. Sohrabnezhad, J. Hazard. Mater. 2010, 178, 349-355.

DOI:10.1016/j.jhazmat.2010.01.086

4. R. D. Ambashta and M. Sillanpaa, J. Hazard. Mater., 2010, 180, 38-49. DOI:10.1016/j.jhazmat.2010.04.105

5. S. H. Chen, J. Zhang, C. L. Zhang, Q. Y. Yue, Y. Li and C. Li, Desalination, 2010, 252, 149-156.

DOI:10.1016/j.desal.2009.10.010

6. M. Cai, J. Su, G. Lian, X. Wei, C. Dong, H. Zhang, M. Jin, Z. Wei, Ultrason. Sonochem. 2016, 31, 193-200.

DOI:10.1016/j.ultsonch.2015.12.017

7. N. Riaz, F. K. Chong, B. K. Dutta, Z. B. Man, M. S. Khan, E. Nurlaela, Chem. Eng. J. 2012, 185-186, 108-119.

DOI:10.1016/j.cej.2012.01.052

8. N. Inchaurrondo, J. Font, C. P. Ramos, P. Haure, Appl. Catal. B: Environ. 2016, 181, 481-494.

DOI:10.1016/j.apcatb.2015.08.022

9. G. P. Anipsitakis, D.D. Dionysiou, Environ. Sci. Technol. 2003, 37, 4790-4797. DOI:10.1021/es0263792

10. Q. Yang, H. Choi, Y. Chen, D. D. Dionysiou, Appl. Catal. B: Environ. 2008, 77, 300-307.

DOI:10.1016/j.apcatb.2007.07.020

11. H. Liang, H. Sun, A. Patel, P. Shukla, Z. H. Zhu, Sh. Wang, Appl. Catal. B: Environ. 2012, 127, 330-335.

DOI:10.1016/j.apcatb.2012.09.001

11. Y. B. Ding, L. H. Zhu, N. Wang, H. Tang, Appl. Catal. B: Environ. 2013, 129, 153-162. DOI:10.1016/j.apcatb.2012.09.015

12. G. Nie, J. Huang, Y. Hu, Y. Ding, X. Han, H. Tang, Chin. J. Catal. 2017, 38, 227-239. DOI:10.1016/S1872-2067(16)62566-4

13. X. Dong, B. Ren, Z. Sun, Ch. Li, X. Zhang, M. Kong, S. Zheng, 
D. D. Dionysiou, Appl. Catal. B: Environ. 2019, 253, 2016 217. DOI:10.1016/j.apcatb.2019.04.052

14. G. P. Anipsitakis, D. D. Dionysiou, Environ. Sci. Technol., 2004, 38, 3705-3712. DOI:10.1021/es035121o

15. J. Deng, S. Feng, X. Ma, Ch. Tan, Sh. Zhou, J. Li, Sep. Purif. Technol., 2016, 167, 181-189.

DOI:10.1016/j.seppur.2016.04.035

16. J. Deng, S. Feng, K. Zhang, J. Li, H. Wang, T. Zhang, X. Ma, Chem. Eng. J. 2017, 308, 505-515.

DOI:10.1016/j.cej.2016.09.075

17. S. N. Su, W. L. Guo, C. L. Yi, Y. Leng, Zh. Ma, Ultrason. Sonochem. 2012, 19, 469-474. DOI:10.1016/j.ultsonch.2011.10.005

18. J. Liu, J. Zhou, Z. Ding, Z. Zhao, X. Xu, Z. Fang, Ultrason. Sonochem. 2017, 34, 953-959.

DOI:10.1016/j.ultsonch.2016.08.005

19. X. Y. Lou, L. X. Wu, Y. G. Guo, C. Chen, Z. Wang, D. Xiao, C. Fang, J. Liu, J. Zhao, S. Lu, Chemosphere 117 (2014) 582-585. DOI:10.1016/j.chemosphere.2014.09.046

20. K. H. Chan, W. Chu, Water Res. 2009, 43, 2513-2521. DOI:10.1016/j.watres.2009.02.029

21. O. S. Furman, A. L. Teel, R. J. Watts, Environ. Sci. Technol., 2010, 44, 6423-6428. DOI:10.1021/es1013714

22. C. D. Qi, X. T. Liu, J. Ma, C. Y. Lin, X. W. Li, H. J. Zhang, Chemosphere, 2016, 151, 280-288.

DOI:10.1016/j.chemosphere.2016.02.089

23. B.-T. Zhang, Y. Zhang, Y. Teng, M. Fan, Crit. Rev. Environ. Sci. Technol. 2015, 45, 1756-1800.

24. G. P. Anipsitakis, E. Stathatos, D. D. Dionysiou, J. Phys. Chem. B 2005, 109, 13052-13055. DOI:10.1021/jp052166y

25. Y. Wang, L. Zhou, X. Duan, H. Sun, E. L. Tin, W. Jin, S. Wang, Catal. Today 2015, 258, 576-584.

DOI:10.1016/j.cattod.2014.12.020

26. E. Saputra, S. Muhammad, H. Sun, H-M. Ang, M. O. Tade', S. Wang, J Colloid Interface Sci 2013, 407, 467-473.

DOI:10.1016/j.jcis.2013.06.061

27. W. Guo, S. Su, C. Yi, Z. Ma, Environ. Prog. Sustain. 2013, 32, 193-197. DOI:10.1002/ep.10633

28. X. Chen, J. Chen, X. Qiao, D. Wang, X. Cai, Appl. Catal. B: Environ. 2008, 80, 116-121. DOI:10.1016/j.apcatb.2007.11.009

29. B.-T. Zhang, Y. Zhang, W. Xiang, Y. Teng, Y. Wang, Chem. Res. Chin. Univ. 2017, 33 (5), 822-827.

DOI: $10.1007 / \mathrm{s} 40242-017-6413-6$

30. W. Zhang, H. L. Tay, S. S. Lim, Y. S. Wang, Z. Y. Zhong, R. Xu, Appl. Catal. B: Environ. 2010, 95, 93-99.

DOI:10.1016/j.apcatb.2009.12.014

31. Q. Yang, H. Choi, D. D. Dionysiou, Appl. Catal. B: Environ. 2007, 74, 170-178. DOI:10.1016/j.apcatb.2007.02.001

32. P. R. Shukla, Sh. Wang, H. Sun, H. M. Ang, M. O. Tadé, Appl. Catal. B: Environ. 2010, 100, 529-534.

DOI:10.1016/j.apcatb.2010.09.006

33. P. R. Shukla, H. Sun, S.B. Wang, H. M. Ang, M. O. Tade', Sep. Purif. Technol., 2011, 77, 230-236.

DOI:10.1016/j.seppur.2010.12.011
34. L. Hu, X. Yang, S. Dang, Appl. Catal. B: Environ. 2011, 102, 19-26. DOI:10.1016/j.apcatb.2010.11.019

35. B.-T. Zhang, Y. Zhang, Y. Teng, Appl. Surf. Sci. 2018, 452, 443-450. DOI:10.1016/j.apsusc.2018.05.065

36. P. Shi, R. Su, F. Wan, M. Zhu, D. Li, S. Xua, Appl. Catal. B: Environ. 2012, 123-124, 265-272.

DOI:10.1016/j.apcatb.2012.04.043

37. M. Kosmulski, Adv. Colloid Interface Sci. 2009, 152, 14-25. DOI:10.1016/j.cis.2009.08.003

38. L. Hu, G. Zhang, M. Liu, Q. Wang, P. Wang Chem. Eng. J. 2018, 338, 300-310. DOI:10.1016/j.cej.2018.01.016

39. M.V. Lopez-Ramon, F. Stoeckli, C. Moreno-Castilla, F. Carrasco-Marin Carbon 1999, 37, 1215-1221. DOI:10.1016/S0008-6223(98)00317-0

40. Z. S. Wu, W. C. Ren, L. Wen, L. Gao, J. Zhao, Z. Chen, G. Zhou, F. Li, H.-M. Cheng, ACS Nano 2010, 4 (6), 3187-3194. DOI:10.1021/nn100740x

41. Z. Ai, Y. Huang, S. Lee, L. Zhang, J. Alloys Compd. 2011, 509, 2044-2049. DOI:10.1016/j.jallcom.2010.10.132

42. T. Tsoncheva, L. Ivanova, J. Rosenholm, M. Linden, Appl. Catal. B: Environ. 2009, 89, 365-374.

DOI:10.1016/j.apcatb.2008.12.015

43. J. Yang, H. Liu, W. N. Martens, R. L. Frost, J. Phys. Chem. C 2010, 114, 111-119. DOI:10.1021/jp908548f

44. H. T. Fan, S. S. Pan, X. M. Teng, C. Ye, G. H. Li, L. D. Zhang, Thin Solid Films 2006, 513, 142-147.

DOI:10.1016/j.tsf.2006.01.074

45. B. Y. Bai, H. Arandiyan, J. H. Li, Appl. Catal. B: Environ. 2013, 142-143, 677-683. DOI:10.1016/j.apcatb.2013.05.056

46. M. Stylidi, D. I. Kondarides, X. E. Verykios, Appl. Catal. B: Environ. 2004, 47, 189-201.

47. Y. H. Guan, J. Ma, X. C. Li, J. Y. Fang, L. W. Chen, Environ. Sci. Technol. 2011, 45, (21), 9308-9314.

DOI:10.1021/es2017363

48. W. D. Oh, Z. Dong, T. T. Lim, Appl. Catal. B: Environ. 2016, 194, 169-201. DOI:10.1016/j.apcatb.2016.04.003

49. P. Hu, M. Long, Appl. Catal. B: Environ. 2016, 181, 103-117. DOI:10.1016/j.apcatb.2015.07.024

50. S. Yang, P. Wang, X. Yang, L. Shan, W. Zhang, X. Shao, R. Niu, J. Hazard. Mater. 2010, 179, 552-558.

DOI:10.1016/j.jhazmat.2010.03.039

51. Y. J. Yao, Y. M. Cai, G. D. Wu, F. Wei, X. Li, H. hen, S. Wang, J. Hazard. Mater. 2015, 296, 128-137.

DOI:10.1016/j.jhazmat.2015.04.014

52. G. P. Anipsitakis, D. D. Dionysiou, Appl. Catal. B: Environ. 2004, 54, 155-163. DOI:10.1016/j.apcatb.2004.05.025

53. P. Neta, R .E. Huie, A. B. Ross, J. Phys. Chem. Ref. Data 1988, 17, 1027-1284. DOI:10.1063/1.555808

54. Y. Yao, H. Chen, C. Lian, F. Wei, D. Zhang, G. Wu, B. Chen, S. Wang, J. Hazard. Mater. 2016, 314, 129-139.

DOI:10.1016/j.jhazmat.2016.03.089

55. Y. Xu, J. Ai, H. Zhang, J. Hazard. Mater. 2016, 309, 87-96. DOI:10.1016/j.jhazmat.2016.01.023 


\section{Povzetek}

$\mathrm{V}$ tej študiji smo pripravili sestavljene okside $\mathrm{Bi}_{2} \mathrm{O}_{3}-\mathrm{Co}_{3} \mathrm{O}_{4}$ in ocenili njihovo katalitično učinkovitost za aktiviranje peroksimonosulfata (PMS) proti razgradnji barvila Acid Orange 7 (AO7). Karakterizacijo sintetiziranih katalizatorjev smo izvedli $\mathrm{z}$ analizami XRD, TEM, XPS, FT-IR in ICP-OES. Povečana bazičnost hibridov $\mathrm{Bi}_{2} \mathrm{O}_{3}-\mathrm{Co}_{3} \mathrm{O}_{4}$ je prispevala $\mathrm{k}$ veliko boljši katalitični aktivnosti pri aktivaciji PMS, kar je povzročilo znatno višjo stopnjo razgradnje AO7 v primerjavi s tisto, ki jo dobimo s samim $\mathrm{Co}_{3} \mathrm{O}_{4}$. Vzorec s 50 mas. $\% \mathrm{Bi}_{2} \mathrm{O}_{3}$ je pokazal najboljše rezultate v širokem območju pH z zelo majhnim uhajanjem Co $(72 \mu \mathrm{g} / \mathrm{L})$ tudi v kislih pogojih. Razgradnja $50 \mathrm{mg} / \mathrm{L}$ AO7 je dosegla skoraj $100 \% \mathrm{v}$ kratkem času (12 minut) $\mathrm{z}$ uporabo zelo nizke koncentracije katalizatorjev $(0,1 \mathrm{~g} / \mathrm{L})$ in $\mathrm{z}$ razmerjem [PMS]/[AO7] = 6. Proučevali smo vpliv vsebnosti $\mathrm{Bi}_{2} \mathrm{O}_{3}$, količine katalizatorja, molskega razmerja [PMS]/[AO7], začetnega $\mathrm{pH}$ in temperature na razgradnjo AO7. S poskusi na osnovi kaljenja radikalov so bili površinsko vezani sulfatni ostanki, ki nastajajo v oksidacijskem sistemu $\mathrm{Bi}_{2} \mathrm{O}_{3}-\mathrm{Co}_{3} \mathrm{O}_{4} / \mathrm{PMS}$, dokazani kot prevladujoča vrsta radikalov. 